\title{
The impact of winter flooding with saline water on foliar carbon uptake and the volatile fraction of leaves and fruits of lemon (Citrus $\times$ limon) trees
}

\author{
Violeta Velikova ${ }^{\mathrm{A}, \mathrm{B}}$, Tommaso La Mantia ${ }^{\mathrm{C}}$, Marco Lauteri ${ }^{\mathrm{A}}$, Marco Michelozzi ${ }^{\mathrm{D}}$, \\ Isabel Nogues ${ }^{\mathrm{A}}$ and Francesco Loreto ${ }^{\mathrm{E}, \mathrm{F}}$

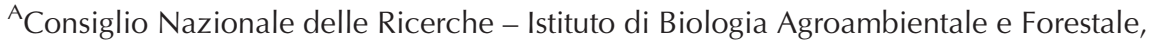 \\ Porano, Terni 05010, Italy. \\ ${ }^{B}$ Bulgarian Academy of Sciences - Institute of Plant Physiology and Genetics, \\ 1113 Sofia, Bulgaria. \\ 'Universita' di Palermo - Dipartimento di Colture Arboree, Facoltà di Agraria, \\ Palermo 90128, Italy.

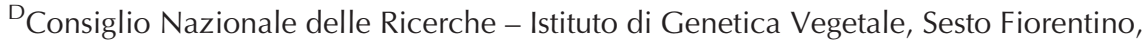 \\ Firenze 50019, Italy. \\ ${ }^{\mathrm{E}}$ Consiglio Nazionale delle Ricerche - Istituto per la Protezione delle Piante, Sesto Fiorentino, \\ Firenze 50019, Italy. \\ FCorresponding author. Email: francesco.loreto@ipp.cnr.it
}

\begin{abstract}
We investigated the consequences of recurrent winter flooding with saline water on a lemon (Citrus $\times$ limon (L.) Burm.f.) orchard, focussing on photosynthesis limitations and emission of secondary metabolites (isoprenoids) from leaves and fruits. Measurements were carried out immediately after flooding (December), at the end of winter (April) and after a dry summer in which plants were irrigated with optimal quality water (September). Photosynthesis was negatively affected by flooding. The effect was still visible at the end of winter, whereas the photosynthetic rate was fully recovered after summer, indicating an unexpected resilience capacity of flooded plants. Photosynthesis inhibition by flooding was not due to diffusive limitations to $\mathrm{CO}_{2}$ entry into the leaf, as indicated by measurements of stomatal conductance and intercellular $\mathrm{CO}_{2}$ concentration. Biochemical and photochemical limitations seemed to play a more important role in limiting the photosynthesis of flooded plants. In young leaves, characterised by high rates of mitochondrial respiration, respiratory rates were enhanced by flooding. Flooding transiently caused large and rapid emission of several volatile isoprenoids. Emission of limonene, the most abundant compound, was stimulated in the leaves, and in young and mature fruits. Flooding changed the blend of emitted isoprenoids, but only few changes were observed in the stored isoprenoids pool.
\end{abstract}

Additional keywords: Citrus, isoprenoids, photosynthesis.

Received 13 October 2011, accepted 30 December 2011, published online 14 March 2012

\section{Introduction}

Salinisation of soils and its negative impact on plant production and quality is an urgent problem worldwide. An increasing amount of soil is subjected to salinity, probably greater today than the $7 \%$ of global land area reported by Munns in 2002 on the basis of data collected during the last decade of the past century (Munns 2002). Pitman and Lauchli (2002) reported that the area that is subjected to salinity ranges from $20 \%$ to an impressive $50 \%$ of the total irrigated lands. Salinisation is generally associated with irrigation with water that has a high salt concentration (Levy and Syvertsen 2004), and therefore salinisation is worse during the dry and warm seasons when irrigation becomes necessary. Arid and semiarid zones are also characterised by high evapotranspiration rates, which may lead to rising saline water tables, a phenomenon known as 'dryland salinity' (Lambers 2003). This may also exacerbate the salinity problem during rainless periods. In the Mediterranean basin, $25 \%$ of the total irrigated land is exposed to saline water (Paranychianakis and Chartzoulakis 2005). In rainy months and in well drained soils, salinisation is generally lessened by leaching (Levy and Syvertsen 2004). However, salinisation may also occur because of an increase in saline ground water levels, for example in tropical regions subjected to high rainfalls (Calvert 1982). In this case, the problem of high salinity is 
often associated with temporary flooding, which is also known to negatively affect the physiology and productivity of plants by oxygen deprivation in the root system (Vartapetian 1991).

Citrus is a high-value horticultural crop that grows preferentially in semiarid areas where irrigation is required to produce maximum yield. Citrus species are considered sensitive to salt (Storey and Walker 1999), although there is considerable variation in sensitivity due to rootstock and cultivar selection (Maas 1993). Salt sensitivity is due to the combination of osmotic and ionic stress, the latter probably being more important in altering Citrus physiology and productivity (Levy and Syvertsen 2004). Citrus trees are also sensitive to flooding (García-Sánchez et al. 2007), as their root system does not withstand long periods of anaerobiosis. Flooding in Citrus can reduce photosynthesis and stomatal conductance (GarcíaSánchez et al. 2007); decrease tree growth, yield and fruit size (Reighard et al. 2001); and increase susceptibility to pests and root loss (Li et al. 2006). Flooding with saline water creates a combination of stresses that can amplify the impact of the single stress (Kozlowski 1997).

In the area of Vendicari, situated in the south-east part of Sicily $\left(36^{\circ} 47^{\prime} 39^{\prime \prime} \mathrm{N} 15^{\circ} 5^{\prime} 45^{\prime \prime} \mathrm{E}\right)$, flooding and high salinity stresses co-occur. The area of Vendicari is largely covered by a natural lagoon system made by three different ponds that were formed in the Hellenistic age (Pirrotta and Barbano 2011). The lagoon was used as salt ponds or for fisheries. It was connected to the sea through canals that were maintained by farmers and allowed a yearly cycle of water management (Ientile et al. 2011). In winter, the ponds were refilled by intrusion of marine water and by the limited contribution of freshwater (both from rain and springs). In summer, the ponds dried and the residual water was conveyed to the sea through the canal system. The Vendicari lagoon system is a humid area of international importance according to the Ramsar (1971) convention. After the $1990 \mathrm{~s}$, the Vendicari area became a natural reserve to protect its rare ecosystem. The management of the reserve has not regularly maintained the canalisation system since then. Consequently, the water cycle inside the ponds has changed. Nowadays, the ponds rarely dry out in summer, which has important consequences on the microclimate and on the ecology of plant and animal components of the natural ecosystem (Ientile et al. 2011). During winter, the water regularly overflows from the ponds onto the surrounding agricultural areas, which are mainly cultivated with typical high-value horticultural crops, namely almond (Prunus dulcis Mill.), olive (Olea europaea L.) and citrus (lemon; Citrus $\times$ limon (L.) Burm.f.) fruit trees.

Our research was carried out in a lemon orchard that has been subjected to winter flooding with saline water for the last 10 years. A detailed characterisation of the photosynthetic carbon metabolism of lemon plants was carried out. Lemon trees are known for the fragrance of their leaves, flowers and fruits. Besides having commercial interest for perfumery, and being an important parameter in fruit quality (Moufida and Marzouk 2003), the stored isoprenoids pool and the blend of volatiles emitted by lemon trees also have a fundamental role in ecological interactions with pollinators (Harborne 2001) and herbivores or pathogens (Salvatore et al. 2004; Yamasaki et al. 2007). Therefore, the impact of combined flooding and salinity on the volatile emissions from leaves and fruits was also investigated.

\section{Materials and methods}

\section{Plant material and experimental conditions}

Measurements were carried out in a Citrus orchard on 50-year-old lemon trees (Citrus $\times$ limon L. cv. Femminello Siracusano, grafted on sour orange (Citrus $\times$ aurantium $\mathrm{L}$.) rootstock). The 5 -ha orchard was planted with $6 \times 6 \mathrm{~m}$ spacing between trees on a field gently sloping towards sea level. The part lying just above sea level ( $\sim 1$ ha wide) has been flooded by the water overflowing the surrounding ponds during the last 10 winters. As a consequence, a $5-10 \mathrm{~mm}$ thick waterbed covers the soils for around one month every winter during the period of heavy rainfalls (November-December). At the time of our measurements in December, a salt $(\mathrm{NaCl})$ concentration of $1.2 \%$ and an electrical conductivity of $1.8 \mathrm{dS} \mathrm{m}^{-1}$ were measured in the water still residing over the flooded area, thus indicating that the floodwaters had a high salinity level.

Measurements were made in the flooded area and in a control area $\sim 300 \mathrm{~m}$ apart and $\sim 1.5 \mathrm{~m}$ above sea level, on plants of the same age. The soil was sandy with a $10 \%$ limestone skeleton and with very low clay content all over the orchard. The characteristics of the soil are consistent with high drainage soil properties.

Measurements were carried out three times to assess plant physiology (a) during or immediately after the flooding (December 2009), (b) at the end of winter (April 2010), and (c) after the irrigation period in summer (September 2010). Summer irrigation was scheduled periodically (every $\sim 15$ days) with travelling sprinklers providing around $300 \mathrm{~L}$ of water per tree $\left(\sim 120 \mathrm{~m}^{3} \mathrm{ha}^{-1}\right)$. The irrigation well was $160 \mathrm{~m}$ deep and provided water with excellent overall quality and salinity below $0.02 \%$.

For the purpose of this experiment, the orchard was divided into 10 plots (five control and five flooded) each made by two rows of trees. On each plot, one representative tree was selected; thus measurements were done on five trees per treatment. Destructive and nondestructive samples were taken from young leaves (still expanding at the time of measurements and about half the size of a fully expanded leaf), and from mature, fully expanded leaves of each selected tree. In December, mature, ready to market fruits from the two locations (flooded and control) were also collected and examined for their characteristic profile of volatile organic compounds.

\section{Leaf $\mathrm{Na}^{+}$and $\mathrm{K}^{+}$and pigment content}

Destructive measurements to determine $\mathrm{Na}^{+}, \mathrm{K}^{+}$and pigment content were carried out on young and mature leaves of flooded and control plants. Twenty leaves were randomly collected from all selected trees and from each experimental period. For cation analysis, leaves were dried at $70^{\circ} \mathrm{C}$ for one week and the dry weight was measured. Dry leaf samples weighing $0.1 \mathrm{~g}$ were digested in high-pressure Teflon tubes (THOMSON Instrument Company, San Diego, CA, USA) with a nitric-perchloric acid mixture $(3: 1, \mathrm{v} / \mathrm{v})$ in a microwave oven (Excel-Shangai EU, Microwave Chemistry Technology Co. Ltd, Hong Kong, China). Digestion consisted 
of four steps: (1) $1 \mathrm{~min}$ at $100^{\circ} \mathrm{C}$ and $250 \mathrm{PSI}$, (2) $1 \mathrm{~min}$ at $140^{\circ} \mathrm{C}$ and $350 \mathrm{PSI}$, (3) $1 \mathrm{~min}$ at $170^{\circ} \mathrm{C}$ and $450 \mathrm{PSI}$, and (4) $12 \mathrm{~min}$ at $200^{\circ} \mathrm{C}$ and 550 PSI. Determination of the two cations was made by atomic absorption spectrophotometry (Analyst 300; Perkin Elmer, Rodgau, Germany) in five replicate samples for each treatment.

For pigment content determination, three discs of $0.6 \mathrm{~cm}$ diameter were collected from young and mature leaves from the two treatments. The disks were weighed and then immersed in the appropriate solution. Chlorophyll and total carotenoids were extracted with $80 \%$ acetone $(2.0 \mathrm{~mL}$ solvent per $0.05 \mathrm{~g}$ leaf tissue), whereas anthocyanins were extracted with $1 \% \mathrm{HCl}$ in methanol (w/v) $(1.5 \mathrm{~mL}$ solvent per $0.05 \mathrm{~g}$ leaf tissue). All extractions were completed in the dark at $4^{\circ} \mathrm{C}$. Spectrophotometric analyses of the pigments were performed using a Perkin-Elmer Lambda Bio20 spectrophotometer (Perkin-Elmer, Norwalk, CT, USA). Total chlorophyll (chlorophyll $a+b$ ) and carotenoids were determined following methods and equations by Lichtenthaler and Wellburn (1983).

The total anthocyanin content was estimated from the difference between absorbance at $536 \mathrm{~nm}$ and $600 \mathrm{~nm}$ (to correct for phaephytin absorbance) and converted to $\mu \mathrm{molg} \mathrm{g}^{-1}$ FW using the molar excitation coefficient of 33000 following the method of Hodges and Nozzolillo (1996).

\section{Gas exchange and chlorophyll fluorescence measurements}

$\mathrm{CO}_{2}$ and $\mathrm{H}_{2} \mathrm{O}$ exchange rates and chlorophyll fluorescence were simultaneously measured over a $2-\mathrm{cm}^{2}$ leaf area using an open gas-exchange system (LI-6400, LI-COR, Lincoln, NE, USA) with an integrated fluorescence chamber head (LI6400-40, LI-COR). Photosynthesis $(A)$, stomatal conductance $\left(g_{\mathrm{s}}\right)$, transpiration $(T)$, intercellular $\mathrm{CO}_{2}$ concentration $\left(C_{\mathrm{i}}\right)$, and the photochemical efficiency in dark-adapted (the maximal quantum efficiency of PSII, $\left.F_{\mathrm{v}} / F_{\mathrm{m}}\right)$ and illuminated leaves $\left(\Phi_{\text {PSII }}\right)$ were then calculated using LI-6400 software. Water use efficiency (WUE) was calculated as $W U E=\mathrm{A} / \mathrm{T}$. Leaves were maintained in darkness for $20 \mathrm{~min}$ before measurement of $F_{\mathrm{v}} / F_{\mathrm{m}}$. The $\Phi_{\mathrm{PSII}}$ was calculated as $\left(F_{\mathrm{m}}{ }^{\prime}-F_{\mathrm{s}}\right) / F_{\mathrm{m}}{ }^{\prime}$ where the prime symbol denotes measurements of maximal $\left(F_{\mathrm{m}}\right)$ and steady-state $\left(F_{\mathrm{s}}\right)$ fluorescence in illuminated leaves (Genty et al. 1989). Nonphotochemical quenching (NPQ), which reflects thermal dissipation of excess light energy, was calculated as $N P Q=\left(F_{\mathrm{m}}-F_{\mathrm{m}}{ }^{\prime}\right) / F_{\mathrm{m}}{ }^{\prime}$ (Bilger and Björkman 1991). Measurements were repeated on all three experimental dates on 10 leaves per treatment: five young and five mature leaves within each treatment. Leaves were selected in the illuminated part of the crown and in shoots that were not attacked by pathogens or herbivores. Measurements were carried out using a flow rate of $500 \mathrm{~mL} \mathrm{~min}^{-1}$ on leaves exposed to $1000 \mu \mathrm{mol}$ photons $\mathrm{m}^{-2} \mathrm{~s}^{-1}$ of incident light intensity. The relative humidity was maintained at $50-60 \%$, and the leaf temperature was set at $30^{\circ} \mathrm{C}$. The selected conditions allowed normalised measurements of gas exchanges while mirroring, as closely as possible, the ambient conditions that were characterised by clear sky, relative humidity $>50 \%$, and temperature ranging between $22^{\circ} \mathrm{C}$ and $24^{\circ} \mathrm{C}$ in
December and April, and between $29^{\circ} \mathrm{C}$ and $32^{\circ} \mathrm{C}$ in September. $\mathrm{CO}_{2}$ concentration was set at $400 \mu \mathrm{mol} \mathrm{mol}^{-1}$ except when the $\mathrm{CO}_{2}$ response was measured. The relationship between photosynthesis and intercellular $\mathrm{CO}_{2}$ concentration $(A)$ $C_{\mathrm{i}}$ ) was measured at $1000 \mu \mathrm{mol}$ photons $\mathrm{m}^{-2} \mathrm{~s}^{-1}$ light intensity, and external $\mathrm{CO}_{2}$ concentrations that varied between 50 and $2000 \mu \mathrm{mol} \mathrm{mol}^{-1}$ after removing the diffusive limitations on $A$ as described by Centritto et al. (2003). The mechanistic model developed by Farquhar et al. (1980) was used for $A / C_{\mathrm{i}}$ curvefitting and estimation of biochemical parameters.

\section{Measurements of volatile fluxes from intact samples}

The volatile fraction of the isoprenoids contained in lemon leaves and fruits was measured as a flux outside of gas exchange cuvettes. This volatile fraction will hereafter be called the volatile isoprenoids. To measure volatile isoprenoid emissions from the leaf samples, a second LI-6400 system, with a $6 \mathrm{~cm}^{2}$ window for leaf gas exchange was used. The same conditions as stated for measurements of other gas exchange parameters were set (see above). When photosynthesis and transpiration were steady, the leaf cuvette output was disconnected from the LI-6400 system, and the flow exiting the cuvette was diverted into a silcosteel cartridge packed with $200 \mathrm{mg}$ of Tenax (Markes International Limited, Llantrisant, UK). A volume of $10 \mathrm{~L}$ of air was pumped through the trap at a rate of $200 \mathrm{~mL} \mathrm{~min}^{-1}$. The cartridge was analysed by gas chromatography-mass spectrometry (GC-MS, Agilent Technologies, Wilmington, DE, USA). The gas chromatograph (GC) was supplied with a UNITY thermal desorber (Markes International Limited), with a splitless injector and an HP-5MS capillary column $30 \mathrm{~m}$ in length, $250 \mu \mathrm{m}$ internal diameter and $0.25 \mu \mathrm{m}$ film thickness. The column oven temperature was kept at $40^{\circ} \mathrm{C}$ for the first $5 \mathrm{~min}$, then increased by $5^{\circ} \mathrm{C} \mathrm{min}{ }^{-1}$ to $250^{\circ} \mathrm{C}$ and maintained at $250^{\circ} \mathrm{C}$ for $2 \mathrm{~min}$. Helium was used as a carrier gas. The concentration of each volatile compound was calculated by comparison with the peak area of the gaseous standard. The GC was calibrated weekly using cylinders with standards of isoprene, monoterpenes and sesquiterpenes at a concentration of 100 parts per billion (Rivoira, Milan, Italy). The compound identification was made using the National Institute of Standards and Technology library provided with the GC-MS ChemStation software (Agilent Technologies). GC peak retention time was substantiated by analysis of parent ions and main fragments on the spectra.

To measure volatile emissions from fruit samples, whole fruits were placed in a 1.7-L glass cuvette. Fruits were exposed to synthetic air made by mixing $\mathrm{O}_{2}, \mathrm{~N}_{2}$ and $\mathrm{CO}_{2}$ from cylinders deprived of contaminants. Atmospheric concentrations of the three gases $(20 \%, 80 \%$ and 390 parts per million, respectively) were set with mass flow controllers (BROOKS Instruments, Dresden, Germany). The air flow was set at $2.0 \mathrm{~L} \mathrm{~min}^{-1}$. During sampling, air temperature, light intensity and relative humidity were maintained at constant levels $\left(30^{\circ} \mathrm{C}\right.$, $1000 \mu \mathrm{mol} \mathrm{m}^{-2} \mathrm{~s}^{-1}$ and $56 \%$, respectively). The outlet of the glass cuvette was connected to a silcosteel cartridge and the flow was pumped through the trap at a rate of $150 \mathrm{~mL} \mathrm{~min}^{-1}$. A volume of $1.0 \mathrm{~L}$ of air was collected. The analyses of volatile emission from fruits, using trap desorption and GC-MS 
determination, were performed as already described above for the leaf measurements.

\section{Measurements of isoprenoid content from stored pools in leaves and fruits}

The composition of the isoprenoid fraction of lemon leaves and fruits was analysed in December 2009. Leaves and fruits were collected in the field and stored at $-80^{\circ} \mathrm{C}$ until analysed at Consiglio Nazionale delle Ricerche - Florence laboratory. At least five leaves and five fruits were collected from the same trees used for physiological measurements. Young and mature leaves were collected from flooded and control plants, while only mature fruits were analysed, since we were interested in assessing the quality of winter production.

\section{Gas chromatography-flame ionization detection determination}

Foliar tissues $(0.2 \mathrm{~g})$ or fruit peel $(0.1 \mathrm{~g})$ were ground in liquid nitrogen and extracted with $2.0 \mathrm{~mL}$ of $N$-pentane; the sample was filtered and a $0.5 \mu \mathrm{L}$ volume was injected in the GC in splitter mode (a 20:1 split ratio; see below for details). Analyses were performed with the AutoSystem XL GC (PerkinElmer) equipped with an automatic sampler for liquid sample injections and with the TotalChrom ${ }^{\mathrm{TM}}$ 6.2.0.0.0.:B27 chromatography software.

The separation of the different enantiomeric monoterpenes was performed on an Elite-Betacydex Betacyclodextrin capillary column $30 \mathrm{~m}$ long and $0.25 \mathrm{~mm}$ in diameter (PerkinElmer). Cyclodextrins and their derivatives are useful tools in inducing asymmetric reactions, and have been used extensively as stationary phases in chromatographic enantioselective separations of a wide variety of chiral compounds (Allahverdiev et al. 1999). GC analysis was carried out using hydrogen as carrier gas at $2.0 \mathrm{~mL} \mathrm{~min}^{-1}$ by a flame ionisation detector at $250^{\circ} \mathrm{C}$ and at an injector temperature of $230^{\circ} \mathrm{C}$. The oven temperature programming started at $40^{\circ} \mathrm{C}$ for $3 \mathrm{~min}$ and increased to $200^{\circ} \mathrm{C}$ at a rate of $1^{\circ} \mathrm{C} \mathrm{min}^{-1}$; the final temperature of $200^{\circ} \mathrm{C}$ was maintained for $10 \mathrm{~min}$. Isoprenoids (mono- and sesquiterpenes) were identified by comparison of retention times with those of standards under the same conditions. High purity components were obtained from Sigma-Aldrich S.r.l., Milan, Italy and Acros, Geel, Belgium. The relative amount (proportion of the profile) of each monoterpene was expressed as a percentage of total monoterpenes, and each sesquiterpene was calculated as a percentage of total monoterpenes plus sesquiterpenes.

\section{Headspace GC-MS determination}

Fruit peel samples $(0.3 \mathrm{~g}$ each) were ground in liquid nitrogen and placed in a glass vial, sealed with Teflon septum and crimped aluminum cap. The vials were stored at $-20^{\circ} \mathrm{C}$ until analysed. Headspace GC-MS was then performed on a GC-MS system from Perkin-Elmer Technologies composed of a GC AutoSystem XL coupled to a TurboMass mass spectrometer. The gas chromatograph was equipped with the column described above, operating with helium as a carrier gas at a constant flow of $3 \mathrm{~mL} \mathrm{~min}{ }^{-1}$. The oven program was as follows: the initial temperature was $40^{\circ} \mathrm{C}$ for $3 \mathrm{~min}$, and then an increase of $1^{\circ} \mathrm{C} \mathrm{min}^{-1}$ brought the final temperature to $200^{\circ} \mathrm{C}$. The inlet temperature was $200^{\circ} \mathrm{C}$. The mass spectrometer was operated with an electron ionisation of $70 \mathrm{eV}$, scanning the mass range from 35 to $350 \mathrm{~m} / \mathrm{z}$. Ion source temperature was $200^{\circ} \mathrm{C}$. The GC-MS control and data elaboration were performed using Perkin-Elmer Technologies TurboMass Chemstation ver. 5.4.2.1617 software. The mass spectrometer was calibrated using perfluorotributhylamine as the calibration standard, using the Chemstation software.

Samples were analysed by means of headspace gas chromatography with a Perkin-Elmer TurboMatrix 40 automatic headspace sampler and using the following conditions: $\mathrm{He}$ (carrier gas) at $3 \mathrm{~mL} \mathrm{~min}^{-1}$; pressurisation time, $5 \mathrm{~min}$; injection time set at $0.05 \mathrm{~min}$ to minimise peak broadening; thermostat temperatures, $80^{\circ} \mathrm{C}$; thermostat times, $30 \mathrm{~min}$.

The analysis of pure standards in the same analytical conditions allowed the attribution of some GC-MS signals. When a pure standard was not available, an identification was attempted comparing the recorded mass spectra with a mass spectrometry spectral database (Wiley Library, http:// onlinelibrary.wiley.com), taking also the chromatographic order of elution into consideration.

\section{Statistical analyses}

Data shown represent the means and s. e. of measurements. Physiological, pigment and mineral data were analysed by a three-factorial ANOVA including the factors treatment (flooded and unflooded), leaf age (young and mature) and season, and their interactions. The results of this factorial analysis are presented in Table 1. The significant difference between treatments (control vs flooded samples) were calculated by Student's $t$-test.

The parameters estimated by $A / C_{\mathrm{i}}$ response modelling (Table 2) were analysed by one way ANOVA and a post hoc Tukey's test was applied.

In the case of isoprenoid emissions and contents, the measurement data were not normally distributed (Kolmogorov-Smirnov one sample test) and were analysed by Kruskall-Wallis and Mann-Whitney nonparametric tests.

Statistical analyses were performed using SYSTAT ver. 12.0 software (Systat Software Inc., San Jose, CA, USA).

\section{Results}

\section{Salt accumulation in leaf tissues}

In December, after the flooding event, $\mathrm{Na}^{+}$concentration was higher in young leaves than in mature leaves (Fig. 1a). However, no difference in $\mathrm{Na}^{+}$concentration between control and flooded treatments was found in young leaves, whereas the accumulation of $\mathrm{Na}^{+}$was significantly higher in flooded than in control mature leaves. In April, at the end of winter, $\mathrm{Na}^{+}$accumulation in young control and flooded plants decreased with respect to those measured in December, whereas the $\mathrm{Na}^{+}$concentration of mature flooded leaves increased. At our final sampling in September, after summer irrigation, the concentration of $\mathrm{Na}^{+}$ decreased in all samples, but was still higher in young leaves than in mature ones. $\mathrm{Na}^{+}$concentration was significantly influenced by the treatment, the leaf age and the season, and 
Table 1. Results of a three-way ANOVA statistical treatment to assess the effects of three independent factors: treatment (flooded and unflooded), leaf age (young and mature) and season (December, April and September) on concentrations of $\mathrm{Na}^{+}$, $\mathrm{K}^{+}$, total chlorophyll (Chl), carotenoids (Car), anthocyanins (Ant), photosynthesis $(A)$, stomatal conductance $\left(g_{\mathrm{s}}\right)$, intercellular $\mathrm{CO}_{2}$ concentration $\left(C_{\mathrm{i}}\right)$, and chlorophyll fluorescence parameters $\left(\Phi_{\mathrm{PSII}}, \mathbf{N P Q}, \boldsymbol{F}_{\mathrm{v}} / \boldsymbol{F}_{\mathrm{m}}\right)$

ANOVA significance level: *, $P<0.05 ; * *, P<0.01 ; * * *, P<0.001 ;$ n.s., not significant

\begin{tabular}{|c|c|c|c|c|c|c|c|c|c|c|c|c|}
\hline & $\mathrm{Na}$ & $\mathrm{K}$ & Chl & Car & Ant & $A$ & $g_{\mathrm{s}}$ & $C_{\mathrm{i}}$ & WUE & $\Phi_{\text {PSII }}$ & NPQ & $\overline{F_{\mathrm{v}} / F_{\mathrm{m}}}$ \\
\hline Treatment & $* * *$ & n.s. & $* *$ & n.s. & $* * *$ & $* *$ & n.s. & $* * *$ & $* * *$ & $*$ & $* * *$ & n.s. \\
\hline Leaf age & $* * *$ & $* * *$ & $*$ & n.s. & $* * *$ & $* * *$ & n.s. & $* * *$ & $* * *$ & $* * *$ & $* *$ & $* * *$ \\
\hline Season & $* * *$ & $*$ & $* *$ & n.s. & $* * *$ & $* * *$ & $* * *$ & $* * *$ & $* * *$ & $* * *$ & $* * *$ & n.s. \\
\hline Treatment $\times$ leaf age & $* * *$ & n.s. & n.s. & n.s. & n.s & n.s. & $* *$ & n.s. & $*$ & $*$ & n.s. & n.s. \\
\hline Treatment $\times$ season & n.s. & n.s. & n.s. & n.s. & $* * *$ & $* *$ & $* * *$ & $* * *$ & $* * *$ & n.s. & $* * *$ & n.s. \\
\hline Leaf age $\times$ season & $* * *$ & $* * *$ & n.s. & n.s. & $* * *$ & $* * *$ & * & $* * *$ & $* * *$ & n.s. & n.s. & n.s. \\
\hline Treatment $\times$ leaf age $\times$ season & $* * *$ & n.s. & n.s. & n.s. & n.s & n.s. & $* *$ & $* * *$ & $* *$ & $*$ & n.s & n.s. \\
\hline
\end{tabular}

Table 2. Maximum Rubisco carboxylase activity $\left(V_{\text {cmax }}, \mu \mathrm{mol} \mathrm{m} \mathrm{m}^{-2} \mathrm{~s}^{-1}\right)$ and maximum rate of electron transport $\left(J_{\max }, \mu \mathrm{mol} \mathrm{m}{ }^{-2} \mathrm{~s}^{-1}\right)$ of young and mature leaves of lemon trees exposed to winter flooding with saline water or grown under control conditions

The two parameters were estimated from $A / C_{\mathrm{i}}$ curve fittings using the biochemical model of Farquhar et al. (1980) and following the procedure outlined by Centritto et al. (2003). Data collected at the end of winter (April) and after the irrigation period in summer (September) are shown as average values and s.e. $(n=5)$. Means were statistically separated by ANOVA and different letters indicate significant differences between means of young and mature leaves of control and flooded trees at $P<0.05$ (Tukey's test)

\begin{tabular}{|c|c|c|c|c|c|c|c|c|}
\hline & \multicolumn{4}{|c|}{ April 2010} & \multicolumn{4}{|c|}{ September 2010} \\
\hline & \multicolumn{2}{|c|}{ Young leaves } & \multicolumn{2}{|c|}{ Mature leaves } & \multicolumn{2}{|c|}{ Young leaves } & \multicolumn{2}{|c|}{ Mature leaves } \\
\hline & Control & Flooded & Control & Flooded & Control & Flooded & Control & Flooded \\
\hline$V_{\text {cmax }}$ & $11.8 \pm 1.1^{\mathrm{d}}$ & $12.5 \pm 2.5^{\mathrm{d}}$ & $50.0 \pm 9.9^{\mathrm{b}}$ & $36.2 \pm 6.8^{\mathrm{b}}$ & $25.0 \pm 1.4^{\mathrm{c}}$ & $20.8 \pm 3.1^{\mathrm{c}}$ & $90.5 \pm 8.7^{\mathrm{a}}$ & $91.7 \pm 10.2^{\mathrm{a}}$ \\
\hline$J_{\max }$ & $36.3 \pm 2.6^{\mathrm{d}}$ & $44.0 \pm 2.0^{\mathrm{c}}$ & $98.5 \pm 10.4^{\mathrm{a}}$ & $65.3 \pm 6.9^{\mathrm{b}}$ & $54.6 \pm 1.7^{\mathrm{b}}$ & $51.0 \pm 3.8^{\mathrm{bc}}$ & $128.3 \pm 12.1^{\mathrm{a}}$ & $113.3 \pm 15.5^{\mathrm{a}}$ \\
\hline
\end{tabular}

by the interaction between leaf age $\times$ season and between the three variables (treatment $\times$ leaf age $\times$ season) (Table 1 ).

The foliar level of $\mathrm{K}^{+}$did not vary significantly due to the treatment; however, in September, a moderate increment of $\mathrm{K}^{+}$ was observed in flooded leaves. $\mathrm{K}^{+}$was always higher in young leaves than in mature leaves (Fig. 1b). A significant interaction between leaf age and season was observed to have an effect on $\mathrm{K}^{+}$accumulation, whereas the treatment did not interact with age or season effects (Table 1).

\section{Pigment analysis}

In December, the total chlorophyll content (chlorophyll $a+b$, Fig. 2a) and the carotenoid content (Fig. 2b) were similar for all treatments and leaf ages. The pigment values of mature control leaves were slightly but not significantly higher than those of flooded trees. No anthocyanins accumulated in the young or mature leaves of flooded or control trees at this sampling time (Fig. 2c).

In April, chlorophylls and carotenoids were higher in the controls than in the flooded plants. The difference was especially significant in the case of mature leaves (Fig. 2a, b). A large accumulation of anthocyanins was observed in lemon leaves in April. Anthocyanin content was higher in control leaves than in flooded leaves of the same age, and higher in young leaves than in mature ones (Fig. 2c).

In September, mature leaves of flooded and control trees did not show any difference in pigment concentrations. In young leaves, the concentration of pigments was generally lower than in April and young control leaves still showed a higher pigment concentration than young flooded leaves (Fig. 2). Factorial ANOVA analysis showed that chlorophyll and anthocyanin contents were significantly influenced by treatment, leaf age and season, whereas carotenoids were unaffected by flooding in both young and mature leaves during the different seasons (Table 1).

\section{Photosynthesis and photosynthetic limitations}

Photosynthesis $(A)$ of both young and mature leaves was low in December, and was significantly lower in flooded plants than in control plants (Fig. $3 a$ ). In April, the $A$ of young leaves decreased further, and was near to compensation point in flooded plants. Photosynthesis of mature leaves, on the other hand, increased significantly in April compared with December, and was higher in control plants than in flooded trees. In September, $A$ was again higher in mature leaves than in young leaves, but no differences were observed between control and flooded plants. Photosynthesis was significantly influenced by treatment, leaf age and season. An interactive effect of leaf age $\times$ season on $A$ was observed. Differences in $A$ between control and flooded trees were also strongly dependent on the season (Table 1).

Although $g_{\mathrm{s}}$ was not significantly affected by flooding and leaf age (Table 1), it followed a similar trend to $A$, being far lower in December than in the other two sampling dates in both leaf types (Fig. 3b). In April, $g_{\mathrm{s}}$ was higher in control than in flooded plants, but this difference was only significant in mature leaves. In September, however, the trend was reversed and the $g_{\mathrm{s}}$ of young and mature leaves of the flooded treatment were higher 


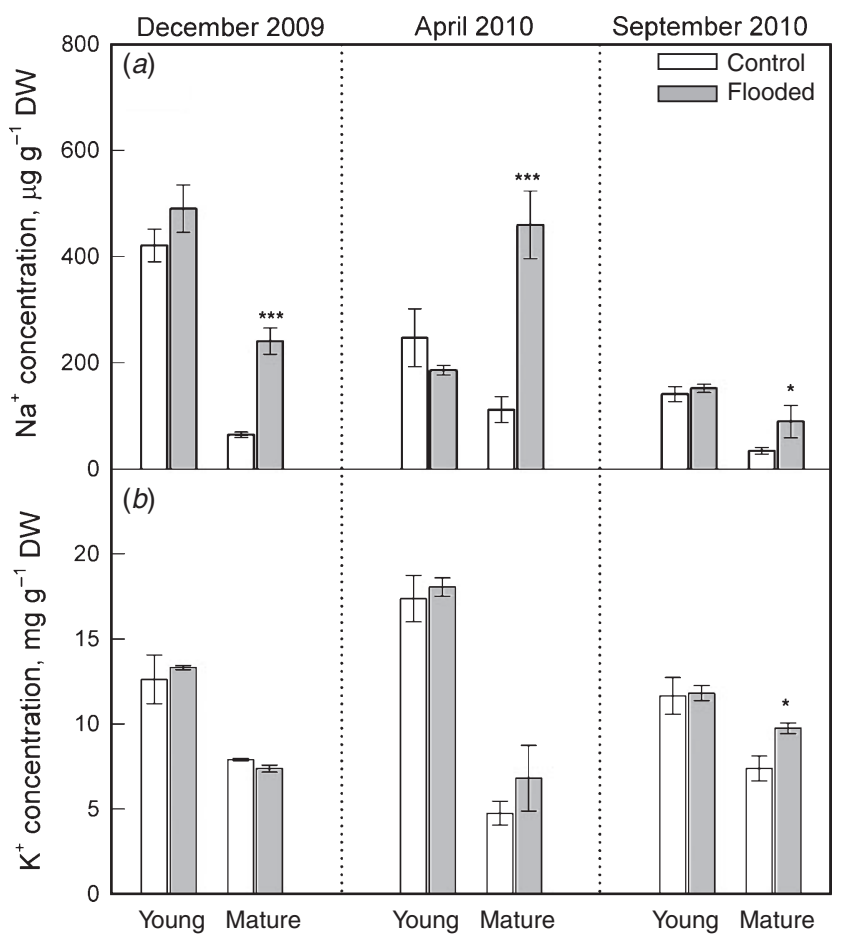

Fig. 1. Changes in $(a) \mathrm{Na}^{+}$and $(b) \mathrm{K}^{+}$concentration in young and mature leaves of lemon trees during flooding with saline water (December), at the end of winter (April) and after the irrigation period in summer (September). Bars represent control (white) and flooded plants (grey). Data are means \pm s.e. of 20 leaves from different plants in each group. Asterisks indicate significant effects at $P<0.05(*)$ and $P<0.001(* * *)$ as assessed statistically by $t$-test on control and flooded sample pairs.

than that of control plants. All variables interacted significantly among them with respect to $g_{s}$.

$C_{\mathrm{i}}$ was significantly higher in flooded than in control leaves in December, whereas in April and September, this difference was less evident or absent (Fig. 3c). $C_{\mathrm{i}}$ was, however, significantly affected by all variables and by their interactions, with the exception of the treatment $\times$ leaf age interaction (Table 1).

The ratio between photosynthesis and transpiration is a measure of the instantaneous WUE of the leaves. WUE was significantly higher in the controls than in the flooded plants in December (Fig. 3d). A similar trend was observed in the WUE of young leaves in April and September, whereas the WUE of mature leaves was similar in control and flooded plants on these two sampling dates. Factorial analysis revealed significant interactions between the three variables in our experimental conditions (Table 1).

The relationship between $A$ and $C_{\mathrm{i}}$ was investigated in April and September (i.e. when photosynthetic rates attained levels that are high enough to make this measurement meaningful in order to assess the biochemical limitations of photosynthesis). In April, the $A$ of young leaves did not respond to increasing intercellular $\mathrm{CO}_{2}$ concentration (Fig. $4 a$ ). In mature leaves, $A$ was largely stimulated by increasing $\mathrm{CO}_{2}$ and the $A$ of control leaves was higher than in flooded leaves even at lower than ambient $\mathrm{CO}_{2}$ levels. In September, $A$ stimulation was again higher in

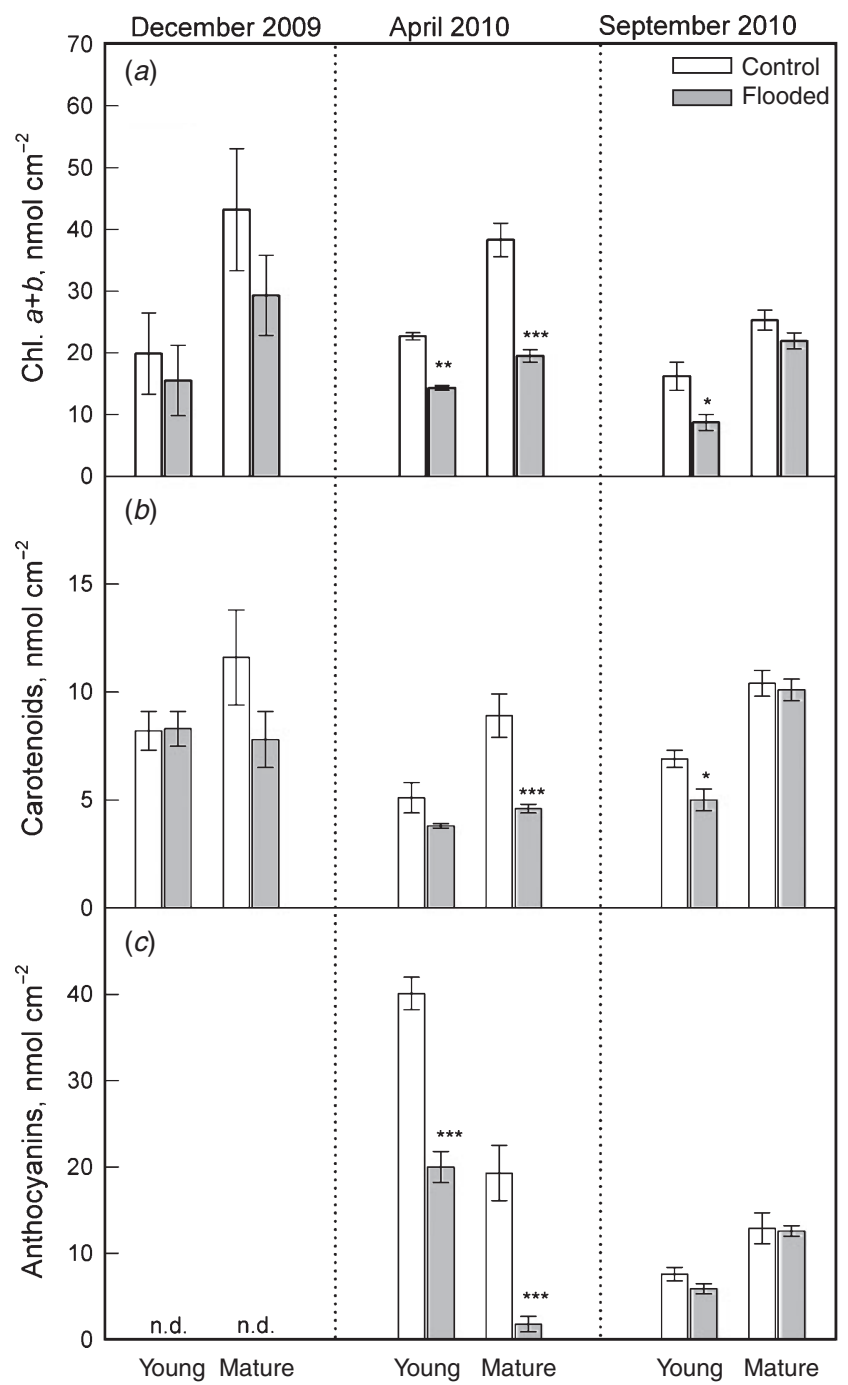

Fig. 2. Changes in (a) total chlorophyll $(\mathrm{Chl} a+b),(b)$ carotenoids and (c) anthocyanins in young and mature leaves of lemon trees during flooding with saline water (December), at the end of winter (April) and after the irrigation period in summer (September). Bars represent control (white) and flooded plants (grey). Data are means \pm s.e. of five plants from each group. Asterisks indicate significant effects at $P<0.05$ (*), $P<0.01$ (**) and $P<0.001(* * *)$ as assessed statistically by $t$-test on control and flooded sample pairs.

mature leaves than in young leaves (Fig. 4b), but control and flooded plants did not show significantly different responses to $\mathrm{CO}_{2}$ (Table 2). $A / C_{\mathrm{i}}$ responses also showed a considerably higher compensation point (the point at which $\mathrm{CO}_{2}$ uptake by photosynthesis is compensated by $\mathrm{CO}_{2}$ release due to photorespiration and mitochondrial respiration) in young leaves of the treated samples compared to mature leaves at both sampling dates. Based on the best-fit curves calculated by the model, the compensation points of young leaves ranged between $301-424 \mu \mathrm{mol} \mathrm{mol}^{-1}$ (April) and 173-178 (September) $\mu \mathrm{mol} \mathrm{mol}^{-1}$, being higher in flooded plants. In mature leaves, the compensation points were between $69 \mu \mathrm{mol} \mathrm{mol}^{-1}$ and $83 \mu \mathrm{mol} \mathrm{mol}^{-1}$ at the same sampling dates. 


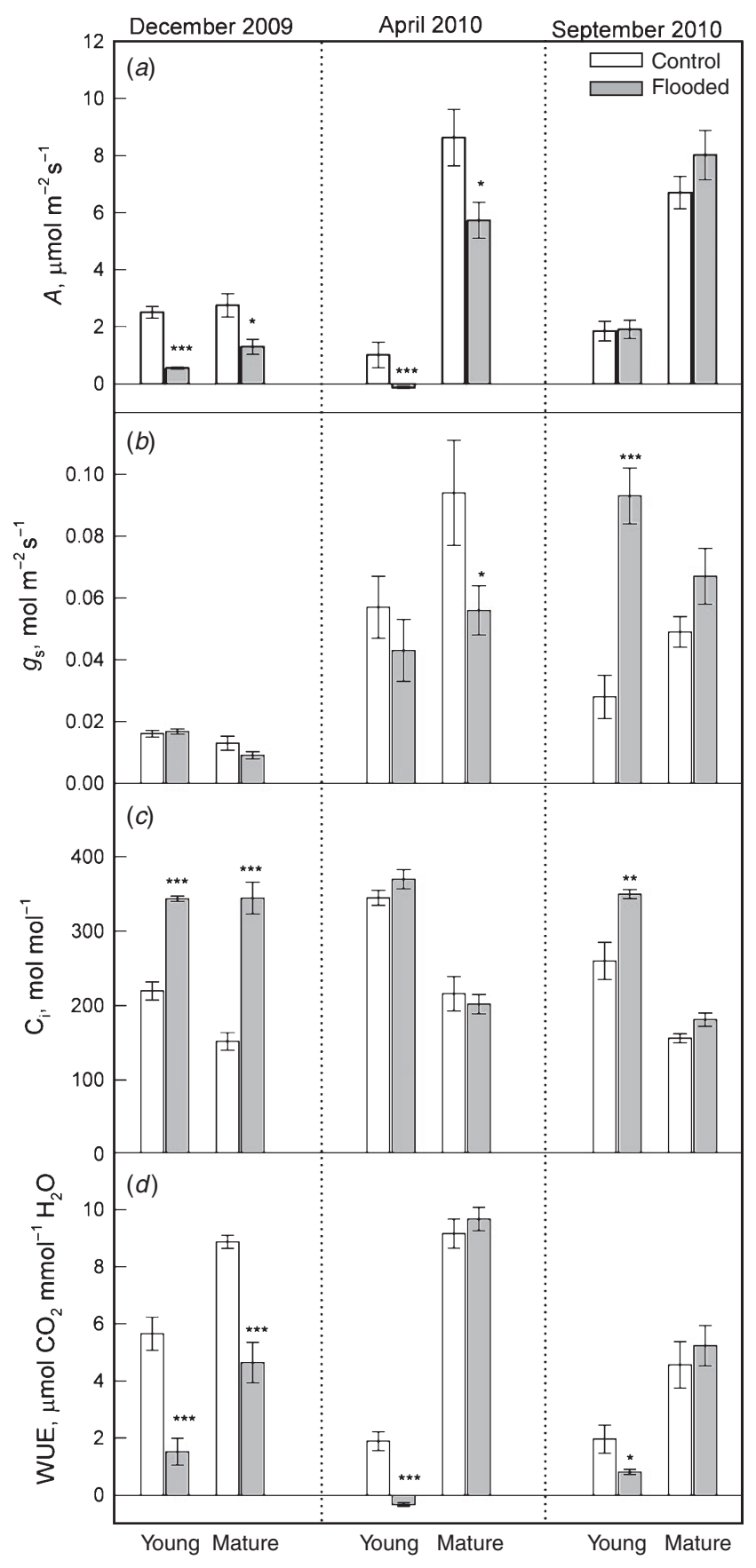

Fig. 3. Changes in $(a)$ photosynthesis $(A),(b)$ stomatal conductance $\left(g_{\mathrm{s}}\right)$, (c) intracellular $\mathrm{CO}_{2}$ concentration $\left(C_{\mathrm{i}}\right)$ and $(d)$ water use efficiency (WUE) in young and mature leaves of lemon trees during flooding with saline water (December), at the end of winter (April) and after the irrigation period in summer (September). Bars represent control (white) and flooded plants (grey). Data are means \pm s.e. of five plants from each group. Asterisks indicate significant effects at $P<0.05\left(^{*}\right), P<0.01(* *)$ and $P<0.001(* * *)$ as assessed statistically by $t$-test on control and flooded sample pairs.

The strong effect of leaf age on the compensation point might be due to higher rates of respiratory activity in young leaves. Indeed, the rates of respiration in the dark (due to mitochondrial respiration only) were found to be significantly higher in young leaves than in mature leaves both in April and September (Fig. 4c, d). Moreover, respiration was significantly increased in response to flooding in both young and mature leaves in April (Fig. 4c), and the effect was still visible, in young leaves only, in September (Fig. $4 d$ ). Biochemical modelling of $A / C_{\mathrm{i}}$ responses suggested that maximum Rubisco carboxylation activity $\left(V_{\text {cmax }}\right)$ was not affected by flooding in both types of leaves and in both sampling periods (Table 2). On the other hand, mature leaves were characterised by a significantly higher $V_{\text {cmax }}$ than young leaves in both flooded and control samples. Model estimates of ribulose-1,5,-bisphosphate regeneration capacity (which can be estimated by maximum rate of photosynthetic electron transport $\left(J_{\max }\right)$; see, for example, Wullschleger 1993 and Wohlfahrt et al. 1999) were also significantly lower in young leaves.

The efficiency of the photochemistry of photosynthesis was analysed by chlorophyll fluorescence. Flooding significantly reduced the photochemical efficiency of PSII $\left(\Phi_{\text {PSII }}\right)$ in mature leaves in December (Fig. 5a). However, flooding did not affect $\Phi_{\text {PSII }}$ in all other sampling periods, irrespective of leaf age. In all sampling dates, $\Phi_{\text {PSII }}$ was clearly lower in young leaves compared with mature leaves (Fig. $5 a$ and Table 1). The NPQ, an indicator of the capacity to dissipate energy nonradiatively, was similar between treatments and leaf ages in December and September (Fig. 5b). However, in April, a much higher NPQ was observed in control leaves than in the leaves exposed to flooding, which made the treatment $\times$ season interaction significant regarding this parameter (Table 1 ).

The maximum quantum yield of PSII photochemistry $\left(F_{\mathrm{v}} / F_{\mathrm{m}}\right)$ occurs in darkened leaves. This fluorescence parameter is an indicator of permanent photochemical damage, mainly related to photoinhibition (Maxwell and Johnson 2000). $F_{\mathrm{v}} / F_{\mathrm{m}}$ was lower in young leaves than in mature leaves in December (Fig. 5c). On this sampling date, the efficiency of PSII was also slightly but significantly inhibited in mature flooded leaves compared with mature controls. In April, the $F_{\mathrm{v}} / F_{\mathrm{m}}$ of control leaves was significantly higher than in flooded leaves of the respective age classes. In September, $F_{\mathrm{v}} / F_{\mathrm{m}}$ was uniformly high in mature flooded and control leaves, whereas young leaves of flooded plants still presented lower maximal photochemical efficiency than the control trees.

\section{Fluxes in leaf and fruit volatiles, and content of isoprenoids from stored pools}

In December, flooding caused a large increase in the emission of volatile isoprenoids from leaves. The most abundant isoprenoids (those with emissions above $3 \mathrm{nmol} \mathrm{m}^{-2} \mathrm{~s}^{-1}$ ) are shown in Fig. 6, whereas the other volatile organic compounds are shown in Table 3. The most abundant isoprenoids emitted were four monoterpenes (limonene, $\beta$-phellandrene, $\alpha$-pinene and linalool). Among the other isoprenoids, the emission of eight more volatiles (monoterpenes: $\beta$-pinene, $\beta$-myrcene, terpinene, $\alpha$-phellandrene, cis- $\beta$-ocimene, 3 -carene and citral, and a sesquiterpene: $\beta$-caryophyllene) was observed in response to flooding. For all these compounds, the flood-induced stimulation was higher in mature leaves than in young leaves (Table 3). 


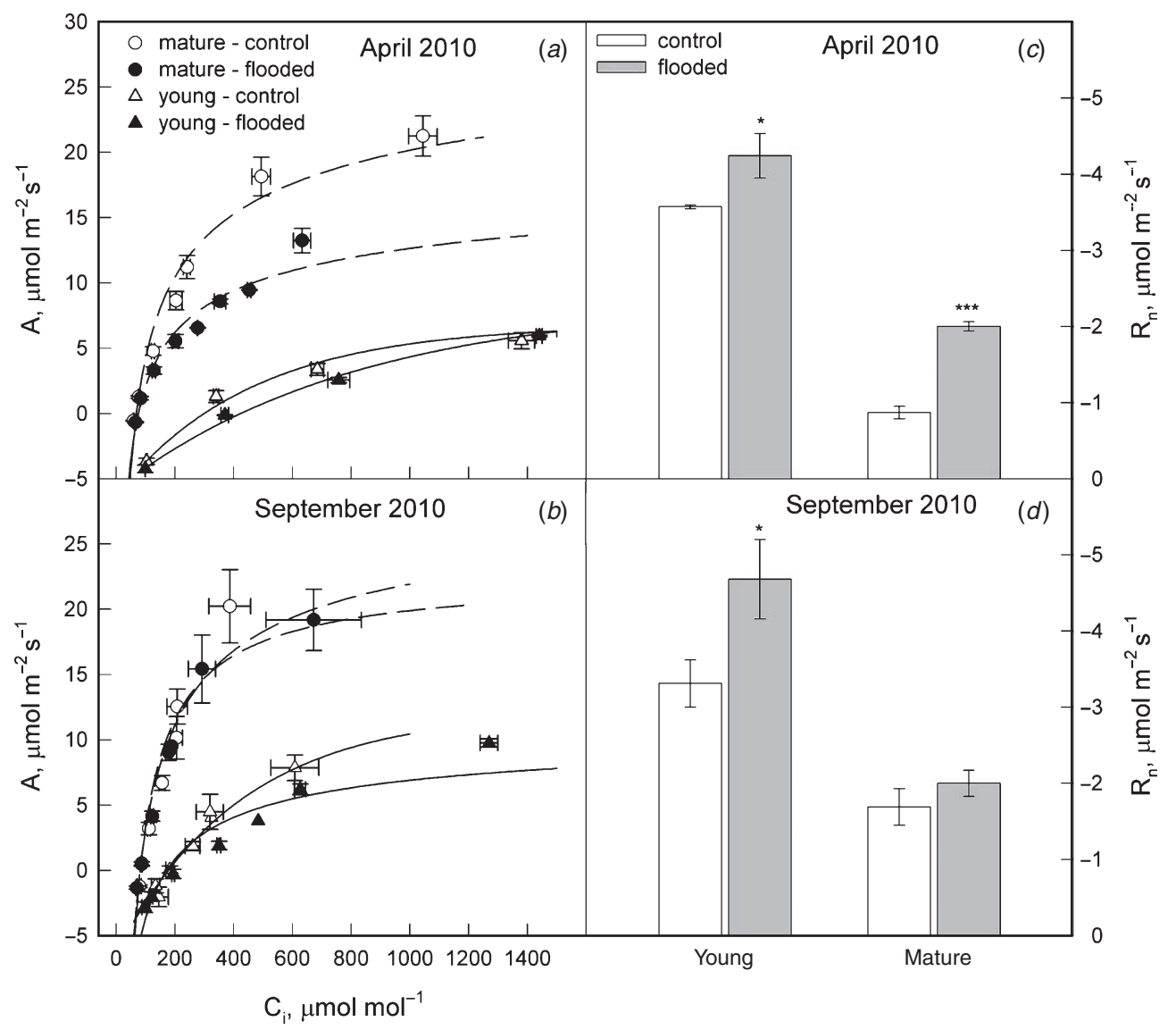

Fig. 4. Photosynthesis response to intercellular $\mathrm{CO}_{2}$ concentration $\left(A / C_{\mathrm{i}}\right.$ response curves) in young and mature leaves measured $(a)$ at the end of winter (April) and $(b)$ after the irrigation period in summer (September). The curve fitting of $A / C_{\mathrm{i}}$ responses is also shown. In the other panels, changes in the dark respiration $\left(R_{\mathrm{n}}\right)$ of young and mature leaves measured in $(c)$ April and $(d)$ September are reported. Bars represent control (white) and flooded plants (grey). Data are means \pm s.e. of five plants from each group. Asterisks indicate significant effects at $P<0.05\left(^{*}\right), P<0.01(* *)$ and $P<0.001\left(^{* * *}\right)$ as assessed statistically by $t$-test on control and flooded sample pairs.

Measurements in April showed a dramatic reduction in all emitted volatile isoprenoids, many of which were below the detection limit, across all treatments and leaf types (Fig. 6, Table 3). However, a large peak of another volatile organic compound, acetone, was observed (Table 3). The acetone peak was significantly higher in young flooded leaves than in young control leaves.

In September, the emission of some volatile isoprenoids was observed again, but the pattern was not as clear as that observed in December. The emission of monoterpenes was generally higher in young than in mature leaves, and sesquiterpenes were not emitted in detectable amounts. The emission of acetone was observed, but only in flooded plants, and to a similar extent in young and mature leaves (Fig. 6, Table 3).

Isoprenoid emission was also measured in young and mature fruits in December. A significant increase of limonene, the main compound in the fruit blend of volatile isoprenoids, was found in young fruits of flooded trees as compared with young fruits of the controls (Fig. 7a). However, the limonene emission by mature fruits was similarly high in control and flooded trees. The other isoprenoids that are minor components of the blend of fruit emission responded differently to the treatment. $\alpha$-Pinene and $\beta$-myrcene were only emitted by mature fruits and this pattern was not altered by the flooding (Fig. $7 b, d$ ). Trans- $\beta$-ocimene was only emitted in control fruits and, to a larger extent, in mature fruits (Fig. 7e). In young and mature fruits of the flooded plants, the emission of trans- $\beta$-ocimene was suppressed to below the detection limit. On the other hand, a stimulation of $\beta$-pinene and terpinene emission was observed in young flooded fruits compared with controls (Fig. 7c, f).

The percent composition of isoprenoids (i.e. the liquid pools of volatile and semivolatile isoprenoids) in the leaves and fruits of lemon trees was also assessed during the December sampling period (Fig. 8). In our analysis, we also discriminated between the enantiomeric forms of several different monoterpenes. This is important because the two enantiomers of chiral monoterpenes might exhibit completely different biological effects (Gershenzon and Dudareva 2007) and can influence the lemon fruit quality (aroma) (Serra 2011).

In both young and mature leaves of the control and flooded plants, $(+)$-limonene and the oxygenated monoterpenes geranial 


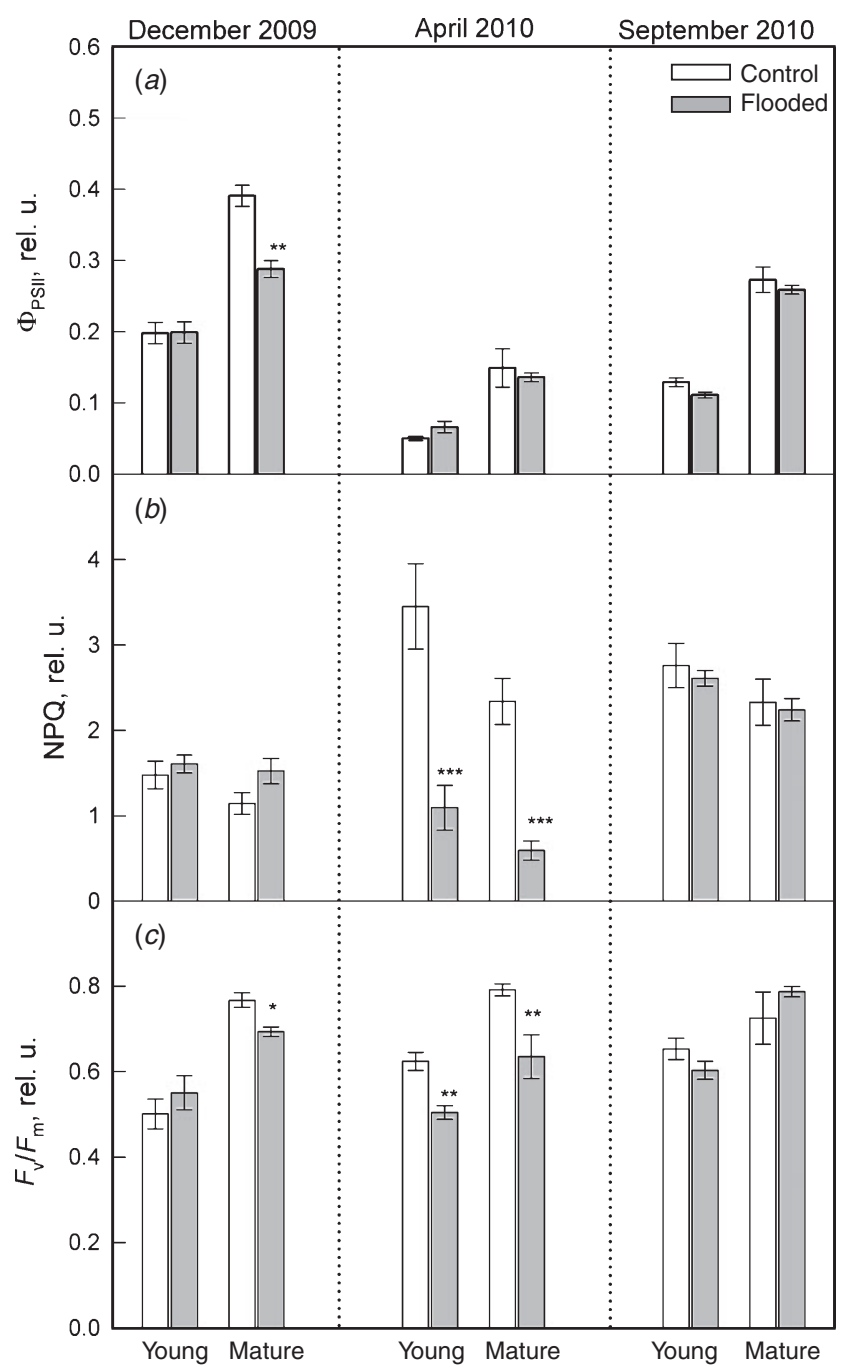

Fig. 5. Changes in (a) quantum efficiency of PSII in light adapted leaves $\left(\Phi_{\mathrm{PSII}}\right),(b)$ nonphotochemical quenching $(\mathrm{NPQ})$ and $(c)$ maximum quantum yield of PSII in dark adapted leaves $\left(F_{\mathrm{v}} / F_{\mathrm{m}}\right)$ in young and mature leaves of lemon trees during flooding with saline water (December), at the end of winter (April) and after the irrigation period in summer (September). Bars represent control (white) and flooded plants (grey). Data are means \pm s.e. of five plants from each group. Asterisks indicate significant effects at $P<0.05(*), P<0.01(* *)$ and $P<0.001 \quad(* * *)$ as assessed statistically by $t$-test on control and flooded sample pairs.

(citral A) and neral (citral B) were the most represented isoprenoids. Differences between young and mature leaves, and between flooded and control plants were only found in a few minor compounds of the foliar isoprenoid blend (Fig. 8). In particular, the percent compositions of 3 -carene, (-)- $\alpha-$ phellandrene and terpinolene were significantly reduced in mature leaves of flooded plants compared to mature leaves of control plants.

A few significant changes were observed in the relative content of major compounds of the fruit isoprenoids, which could be related to the flooding (Fig. 9). In particular, the percent content of $(+)$-limonene, which represents $70-80 \%$ of the total isoprenoids in lemon fruits, was reduced significantly in

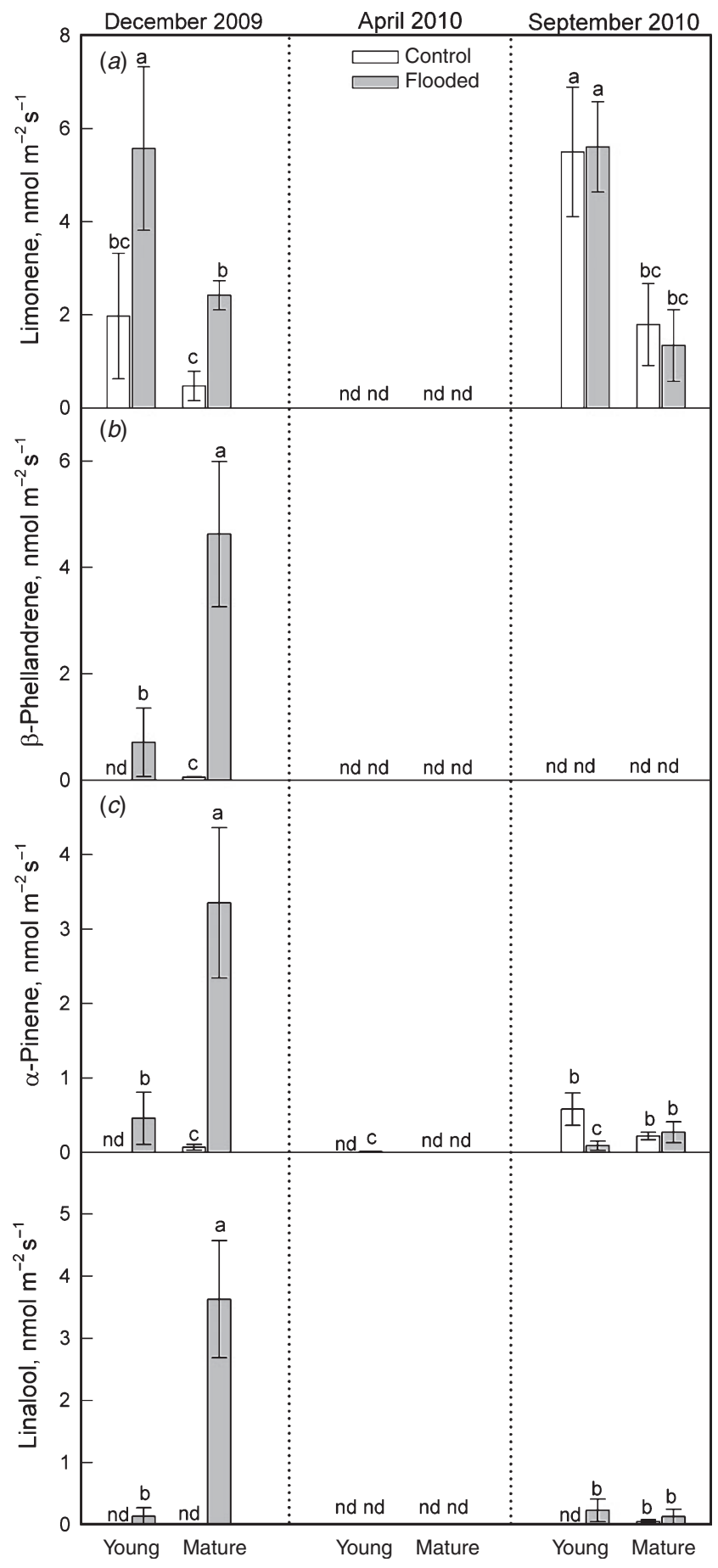

Fig. 6. Changes in the most abundant volatile isoprenoids released from young and mature leaves of lemon trees during flooding with saline water (December), at the end of winter (April) and after the irrigation period in summer (September). (a) limonene; (b) $\beta$-phellandrene ; $(c) \alpha$-pinene; $(d)$ linalool. Bars represent control (white) and flooded plants (grey). Data are means \pm s.e. of five plants from each group. Different letters indicate significant effects at $P<0.05$.

flooded fruits in comparison to the controls. On the other hand, the percent contents of geranial and neral were increased significantly by the flooding treatment. 
Table 3. Changes in the volatile organic compounds emitted $\left(\mathrm{nmol} \mathrm{m}^{-2} \mathrm{~s}^{-1}\right)$ from young and mature leaves of lemon trees during flooding with saline water (December), at the end of winter (April) and after the irrigation period in summer (September)

Data are means \pm s.e. of five plants from each group. Undetectable emissions are labelled as n.d. Different letters indicate statistically significant differences between means of controls and flooded plants $(P<0.05)$.

\begin{tabular}{|c|c|c|c|c|c|c|c|c|c|c|c|c|}
\hline & \multicolumn{4}{|c|}{ December 2009} & \multicolumn{4}{|c|}{ April 2010} & \multicolumn{4}{|c|}{ September 2010} \\
\hline & \multicolumn{2}{|c|}{ Young leaves } & \multicolumn{2}{|c|}{ Mature leaves } & \multicolumn{2}{|c|}{ Young leaves } & \multicolumn{2}{|c|}{ Mature leaves } & \multicolumn{2}{|c|}{ Young leaves } & \multicolumn{2}{|c|}{ Mature leaves } \\
\hline & Control & Flooded & Control & Flooded & Control & Flooded & Control & Flooded & Control & Flooded & Control & Flooded \\
\hline & $0.1 \pm 0.0^{\mathrm{c}}$ & $0.5 \pm 0.2^{\mathrm{b}}$ & $0.1 \pm 0.0^{\mathrm{c}}$ & $1.3 \pm 0.3^{\mathrm{a}}$ & $0.1 \pm 0.0^{\mathrm{c}}$ & $0.1 \pm 0.0^{\mathrm{c}}$ & $0.1 \pm 0.0^{\mathrm{c}}$ & & $0.4 \pm 0.2^{\mathrm{b}}$ & $1.0 \pm 0.4^{\mathrm{a}}$ & $.4 \pm 0.3^{\mathrm{b}}$ & $0.2 \pm 0.0^{\mathrm{b}}$ \\
\hline & & $0.4 \pm 0.1^{\mathrm{a}}$ & n.d. & $0.5 \pm 0.0^{\mathrm{a}}$ & n.d. & n.d. & n.d. & & $0.8 \pm 0.3^{\mathrm{a}}$ & $0.2 \pm 0.1^{\mathrm{b}}$ & $0.5 \pm$ & $3 \pm 0.2^{\mathrm{ab}}$ \\
\hline Terpinene & n.d. & $0.1 \pm 0.1^{\mathrm{b}}$ & n.d. & $0.5 \pm 0.1^{\mathrm{a}}$ & n.d. & n.d. & n.d. & n.d. & $0.3 \pm 0.1^{\mathrm{ab}}$ & $0.4 \pm 0.1^{\mathrm{a}}$ & $0.2 \pm 0.1^{\mathrm{b}}$ & n.d. \\
\hline$\alpha$-Phellandrene & n.d. & $0.4 \pm 0.4^{\mathrm{a}}$ & n.d. & $0.2 \pm 0.0^{\mathrm{a}}$ & n.d. & n.d. & n.d. & n.d. & n.d. & n.d. & n.d. & n.d. \\
\hline cis- $\beta$-Oci & n.d. & $0.4 \pm 0.2$ & n.d. & n.d. & n. & n.c & n.d. & n.c & $\mathrm{n}$. & n.c & n. & n.d. \\
\hline 3-Carene & n.d. & $0.3 \pm 0.0^{\mathrm{a}}$ & n.d & $0.1 \pm 0.0^{\mathrm{b}}$ & $\mathrm{n}$. & n.d. & n.d. & n.d & $\mathrm{n}$. & n.c & n.d. & n.d. \\
\hline Caryophyllene & n.d. & n.d. & n.d. & $0.1 \pm 0.0$ & n.d. & n.d. & n.d. & n.d. & n.d. & n.d. & n.d. & n.d. \\
\hline Citral & $0.1 \pm 0.0^{\mathrm{b}}$ & $0.4 \pm 0.0^{\mathrm{a}}$ & n.d. & $0.1 \pm 0.0^{\mathrm{b}}$ & n.d. & n.d. & n.d. & n.d. & n.d. & n.d. & n.d. & n.d. \\
\hline Acetone & n.d. & n.d. & n.d. & n.d. & $11.3 \pm 4.2^{\mathrm{b}}$ & $32.1 \pm 2.4^{\mathrm{a}}$ & $1.1 \pm 0.0^{\mathrm{c}}$ & $1.2 \pm 0.3^{\mathrm{c}}$ & n.d. & $4.4 \pm 4.4^{\mathrm{c}}$ & n.d. & $8.5 \pm 4.0^{\mathrm{bc}}$ \\
\hline
\end{tabular}

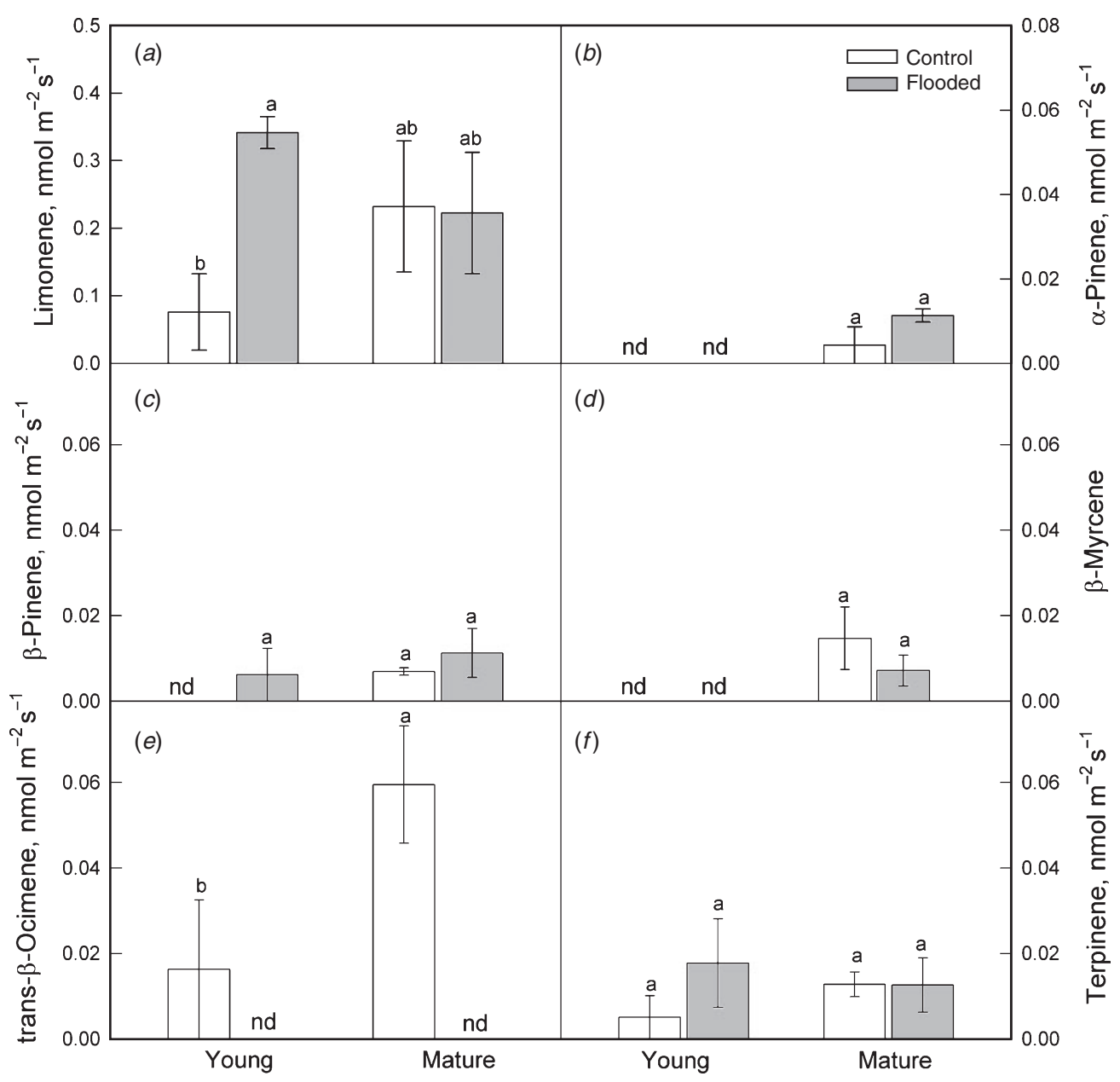

Fig. 7. Volatile isoprenoid emission from whole young and mature lemon fruits measured during flooding with saline water (December). (a) limonene; (b) $\alpha$-pinene; (c) $\beta$-pinene; (d) $\beta$-myrcene; (e) trans- $\beta$-ocimene; $(f)$ terpinene. Bars represent control plants (white), and flooded plants (grey). Data are means \pm s.e. of five plants from each group. Different letters indicate significant effects at $P<0.05$. 


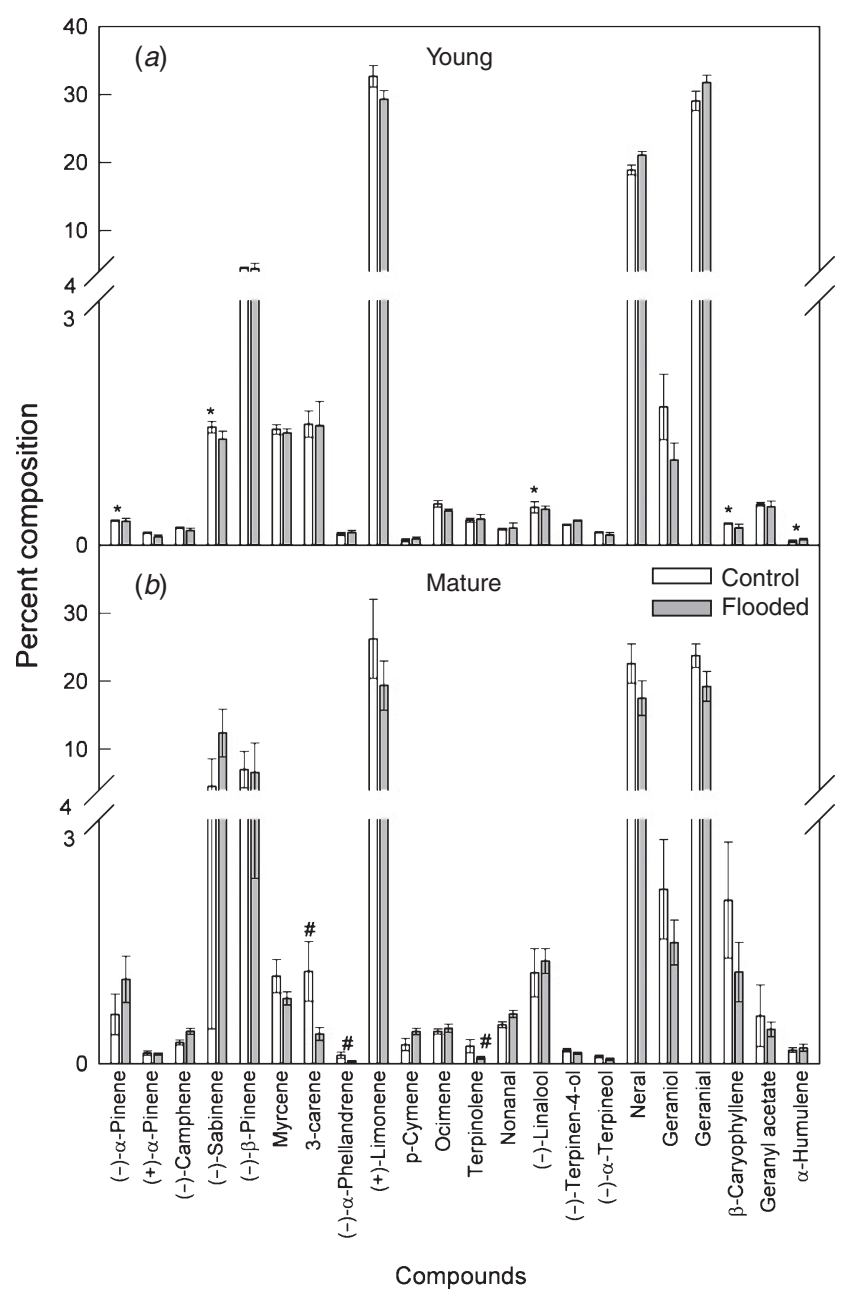

Fig. 8. Isoprenoid pool composition (\%) of ( $a$ ) young and $(b)$ mature lemon leaves of control (white bars) and flooded plants (grey bars) measured during flooding with saline water (December). Data are means \pm s.e. of five plants from each group. Data were analysed by the nonparametric Mann-Whitney test. * indicates significant differences between young mature leaves of control; \# indicates significant differences between control and flooded plants.

\section{Discussion}

The combination of flooding and saline water is a rare event in nontropical areas such as the Mediterranean basin. In the lagoon of Vendicari, the management of the canal system that traditionally allowed excess water to drain from the ponds to the sea in winter, and to dry out the ponds in summer, has been abandoned in recent years. This causes water to overflow above cultivated areas that surround the ponds during the heavy rainfall season, generally concentrated at the end of autumn and the beginning of winter. This management provides a case study for investigating the impacts and responses of a Citrus orchard to such a combined and repeated event. Our study only focusses on physiological traits, and specifically addresses the impacts of flooding on primary metabolism that may in turn affect growth and productivity, and on secondary metabolites that constitute the volatile fractions of leaves and fruits, as these are important

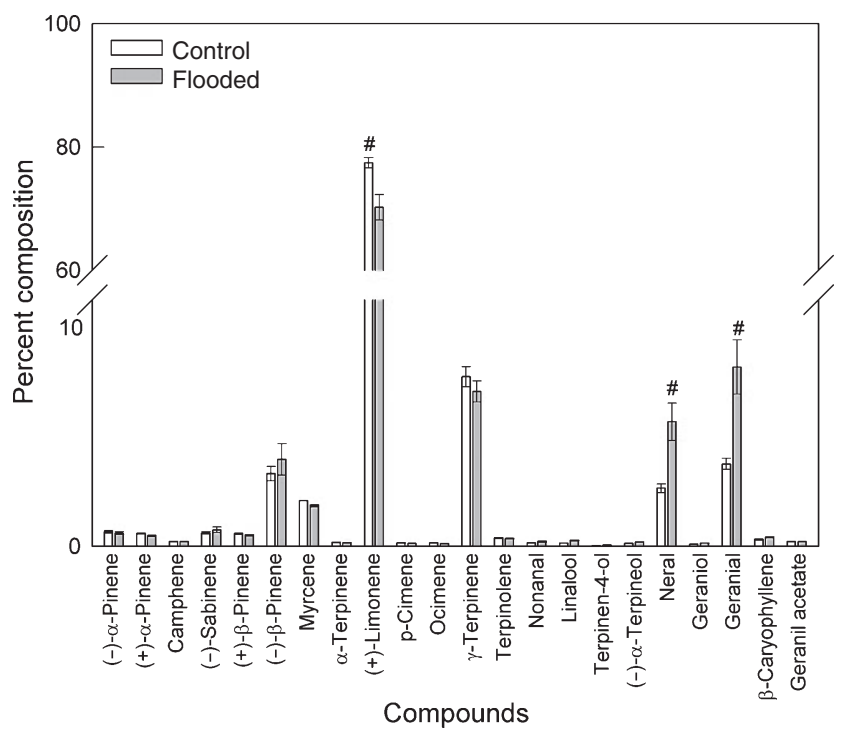

Fig. 9. Isoprenoids pool composition (\%) of fruit peel of lemons from control (white bars) and flooded plants (grey bars). Fruits were collected during flooding with saline water (December). Data are means \pm s.e. from five plants from each group. Data were analysed by the nonparametric Mann-Whitney test; \# indicates significant differences between control and flooded plants.

features for communication with pollinators and pests, and for the quality of lemon fruits.

\section{Salt accumulation}

An interesting initial observation was that $\mathrm{Na}^{+}$accumulation varied among leaves of different ages over the season. Overall, we expected a much higher foliar $\mathrm{Na}^{+}$accumulation due to the fact that flood water was heavily salinised, and because salt uptake is thought to be linearly related to salt accumulation in the soil (Nieves et al. 1992). Sour orange is defined as a rootstock that is susceptible to salinity (Levy and Syvertsen 2004) but is also known to efficiently restrict $\mathrm{Na}^{+}$uptake and transport (Maas 1993). This might have limited salt uptake in our experimental system. Salt accumulation is also known to influence the uptake of other cations (Syversten and Yelenosky 1988). However, no effect was found in the accumulation of $\mathrm{K}^{+}$between flooded and control plants, again suggesting that salt accumulation was not so large as to affect ion uptake significantly. Perhaps the most striking observation was that $\mathrm{Na}^{+}$accumulation mainly occurred in the young leaves in December (i.e. immediately after flooding). Sodium and $\mathrm{Cl}^{-}$accumulate preferentially in the older leaves of Citrus plants (Syvertsen et al. 1988). Unfortunately, we did not measure $\mathrm{Cl}^{-}$accumulation and are unable to say whether this also accumulates in young leaves due to the combination of flooding and salinity. In December, we also observed a very low stomatal conductance $\left(g_{\mathrm{s}}\right)$, mirroring a low transpiration rate that could have contributed to the reduced salt uptake. Since $g_{\mathrm{s}}$ was particularly low in mature leaves, the xylematic transport of salt in winter was possibly redirected towards young leaves. Indeed, in April, under higher $g_{\mathrm{s}}$ and transpiration, $\mathrm{Na}^{+}$accumulation was higher in mature leaves than in young flooded leaves, confirming previous results in 
Citrus (Syvertsen et al. 1988). Finally, the measurements carried out in September revealed that summer irrigation with nonsaline water was sufficient to leach out salinity, as the $\mathrm{Na}^{+}$ concentration was similarly low in all samples.

\section{Primary metabolism}

Flooding with saline water reduced photosynthesis in both young and mature leaves immediately after plants were flooded and until the beginning of spring, when mature leaves had high photosynthetic rates. The inhibition of photosynthesis was never associated with a reduction in $C_{\mathrm{i}}$. In fact, $C_{\mathrm{i}}$ increased significantly in December in flooded leaves, indicating the onset of nonstomatal (i.e. nondiffusive) limitations of photosynthesis. Our results therefore confirm earlier reports that flooding has a very rapid negative effect on photosynthesis (Kozlowski 1997; Arbona et al. 2009; Hossain et al. 2009) and that biochemical or photochemical factors enhance photosynthesis limitation in flooded (Schaffer et al. 1992; Arbona et al. 2009; Hossain et al. 2009) or salt-stressed (Kozlowski 1997) plants. Photosynthesis inhibition was not observed in September in flooded plants. Clearly, summer irrigation, which reduced salinity to control levels, is sufficient to restore full functionality of the photosynthetic apparatus.

Analysing $A / C_{\mathrm{i}}$ responses provides insights into biochemical limitations (Sharkey et al. 2007) and chlorophyll fluorescence reveals photochemical limitations (Baker et al. 2007) to photosynthesis. From $A / C_{\mathrm{i}}$ responses, it can be inferred (Farquhar and Sharkey 1982; Sharkey et al. 2007) that the substantial difference between mature and young leaves during the measurement periods, and in particular in April and September when considerably higher photosynthetic rates can be reached, was caused by the following features of young leaves: (a) a much lower Rubisco activity, as indicated by the lower slope of the $A / C_{\mathrm{i}}$ response at low $\mathrm{CO}_{2}$ concentrations; (b) a lower capacity to regenerate RuBP, in turn due to inefficient photochemistry (see also below); and (c) a significantly higher mitochondrial respiration that increased the compensation point and was also clearly seen when measuring the rates of dark respiration. In April, a comparison between flooded and control trees indicated the occurrence of similarly heavy photosynthetic limitations in young leaves. However, in mature flooded leaves, the RuBP limitation due to inefficient electron transport regeneration in photosynthetic substrates was larger than in mature control leaves, as shown by the lower plateau of the flat part of the $A / C_{\mathrm{i}}$ response. In September, no significant differences were found in the $A / C_{\mathrm{i}}$ responses between flooded and control plants, confirming that the effect of flooding was completely alleviated, with no residual photosynthetic limitation at the Rubisco and RuBP level.

It was interesting to observe that flooding significantly increased the rate of mitochondrial respiration in young and mature leaves in April, and still affected the respiration of young leaves in a similar way in September. Perhaps increasing mitochondrial respiration indicates a general increase in catabolic processes under flooding, possibly related to higher enzyme activities in the glycolytic pathway (Kennedy et al. 1992) caused by higher demand of carbohydrates for fermentation processes at the root level (Loreti et al. 2005).
Young leaves also showed a generally lower maximal photochemical capacity (as indicated by the fluorescence parameter $F_{\mathrm{v}} / F_{\mathrm{m}}$; Maxwell and Johnson 2000) compared to mature leaves at all seasonal stages. This explains the lower capacity of RuBP regeneration indicated by the $A / C_{\mathrm{i}}$ responses. Flooding significantly affected the maximal photochemical capacity but this was more visible in mature leaves (showing higher photochemical capacity than younger leaves) both immediately after flooding (December) and overwintering (April). Overall, our findings indicate that the young Citrus leaves may have experienced photoinhibition and that this was exacerbated by flooding in overwintering leaves (Arbona et al. 2009). Photochemical limitations to photosynthesis were completely alleviated in September, again indicating a total resilience to the stressful conditions due to flooding. When photons cannot be used to generate photosynthetic electron transport, the light energy is generally dissipated as heat (Müller et al. 2001). Surprisingly, however, the NPQ, which estimates heat-dissipated light energy, did not increase when the photochemistry of photosynthesis was downregulated by flooding. In fact, in April, the NPQ was highest in young and mature control leaves, in which photosynthesis and maximal photochemical efficiency were also higher than in flooded plants. This may indicate that flooding reduced the number of photosynthetic reaction centres or the ability to dissipate excess light. Such a reduction of photochemical capacity is generally observed in plants that also show a strong reduction of photosynthetic pigments in response to abiotic stress. Salinity (Syvertsen et al. 1988) and flooding (Arbona et al. 2008) often induce leaf chlorophyll degradation. We observed such an effect on the chlorophyll and carotenoid content of leaves of flooded plants that overwintered. The effect was still visible in September, but only in young leaves that had lowest photochemical efficiency. Pigment analysis also revealed that the anthocyanin formation typical of overwintering leaves that experience cold stress (Hughes and Smith 2007) was significantly attenuated in flooded plants in April. Since anthocyanins may also protect the photochemical apparatus by absorbing light, reacting as antioxidants or increasing leaf temperature (Hatier and Gould 2009), increasing photodamage in flooded and overwintered Citrus leaves may also be attributed to inhibition of biosynthesis of important pigments, especially in young leaves in which the photosynthetic capacity is still constitutively low.

\section{Volatile isoprenoid emission, and foliar and fruit isoprenoid pools}

The impact of flooding and salinity on secondary metabolites is important to assess in Citrus plants, as these components of foliar and flower scent and fruit flavour drive communication between plants and herbivores or pollinators (Dicke and Baldwin 2010), and also strongly influence fruit quality and have important roles in medicine (Fisher and Phillips 2008). Foliar emission of volatile isoprenoids showed a clear seasonal pattern and was generally enhanced immediately after flooding in young and mature leaves. The blend of emitted volatiles also changed in flooded plants, as some volatiles (e.g. $\beta$-myrcene, terpinene, $\alpha$-phellandrene, $\beta$-ocimene and 3 -carene), which were 
not detected in control leaves, were emitted in high concentration from flooded plants in December. The overall stimulation of volatile isoprenoids was limited to December, and therefore we believe it was a transient effect of flooding. However, our findings suggest that, firstly, the methylerythritol-phosphate pathway of isoprenoid biosynthesis and emission was transiently stimulated by flooding. As the functions of volatile isoprenoids include an antioxidant role (Loreto and Schnitzler 2010), they possibly help plants cope better with general oxidative stress induced by flooding (Arbona et al. 2008). Secondly, isoprenoid emission is not controlled at the genetic level only, and may be altered by flooding and probably other environmental stresses. Thirdly, flood-induced changes in the volatile blend may temporarily alter communication with plant hosts; in the case of lemon trees, emission changes due to winter flooding may interact with mite infestations in particular (Choi et al. 2004) or fungi attacks (Yamasaki et al. 2007), or in communication with pollinators. None of these interactions were assessed in our experiment but our results may lay the ground work for further investigations in this field.

The emission of acetone was not detected in December, but this oxygenated compound was largely emitted in April, especially from young leaves, and the emission was further stimulated in flooded plants. The emission of acetone is seasonal in plants. A large acetone emission was reported by Fares et al. (2011) from orange (Citrus $\times$ sinensis (L.) Osbeck) and lemon (Citrus $\times$ limon (L.) Burm.f.) leaves. Acetone emission may indicate active growth (Fares et al. 2009) and consequent metabolism of fat reserves (Sharkey 1996). This explains the high emission rates from young lemon leaves observed in April. Acetone emission may also indicate fatty acid destruction during leaf senescence (de Gouw et al. 1999) or caused by environmental stresses (Cojocariu et al. 2005). An emission of acetaldehyde was also expected after flooding, as this volatile molecule is synthesised from ethanol formed in anoxic roots and then translocated to the canopy of plants (Loreto and Schnitzler 2010). However, acetaldehyde emission was not found in Citrus plants, and we speculate that the very low stomatal conductance restrained acetaldehyde emission and possibly also emission of other oxygenated volatiles (Loreto and Schnitzler 2010) immediately after flooding.

In December, the isoprenoid composition inside leaves showed only minor changes in flooded leaves in comparison to the controls. This confirms that flooding caused an overall increase in isoprenoids biosynthesis, as indicated by the general increase of volatile isoprenoid emissions. Salinity is known to affect fruit size and number (Nieves et al. 1990). As for the biochemical traits of Citrus fruits, only sugar content and total soluble solids appear to be affected by salt (Prior et al. 2007), but the effect of salt is controversial (Maas 1993). Levy and Syvertsen (2004) speculated that salinity stress might enhance the concentration of secondary metabolites in the fruit. The impact of flooding on fruit characteristics, to our knowledge, has not been well investigated (Kozlowski 1997). Our results support the idea of Levy and Syvertsen (2004) that flooding with saline water may enhance secondary metabolite production in Citrus fruits. However, there was no common pattern in the emission of volatile isoprenoids from lemon fruit. In the case of limonene, the most characteristic and abundant volatile in lemon juice (Di Vaio et al. 2010), emissions significantly increased only in young fruits after flooding. However, of the blend of volatile isoprenoids that are emitted in low amounts, trans- $\beta$-ocimene was totally suppressed after flooding. Changes in emissions may not reflect changes in the overall composition of the internal pool of isoprenoids in lemon fruits. In fact, the internal pool of isoprenoids was remarkably stable. Thus, in agreement with plant chemosystematic studies showing that constitutive terpenes from stored pools are under strong genetic control and are not affected greatly by abiotic stress (Langenheim 1994), the stored isoprenoid profile can be used as a biochemical marker to characterise different Citrus species and cultivars (Lota et al. 2002). However, as significant differences between flooded and control plants were observed when comparing some of the most abundant fruit monoterpenes, flooding may affect overall fruit quality and defence mechanisms. These possibilities should be assessed in future studies.

\section{Conclusions}

It was shown that recurrent flooding with saline water may have a series of consequences on lemon physiology and fruit quality. From a physiological standpoint, the photosynthetic properties of lemon leaves were heavily reduced by the winter flooding stress, but the plants showed an unexpected resilience, eventually leading to recovery of photosynthetic performances by September of the next year, when salt concentration in the leaves returned to levels similar to those of the controls, probably due to irrigation with good quality water and consequent salt leaching. The biosynthesis and emission of foliar and fruit volatile compounds were also significantly affected by the combined stress (flooding and salinity), but few changes in the internal pools of isoprenoids occurred in flooded plants in comparison to the controls. Variations in the emission of volatile compounds and in the stored isoprenoid pools may lead to qualitative changes of production, and it is an important field for further studies.

\section{Acknowledgements}

This research was supported by the Regione Siciliana, Assessorato Risorse Agricole e Alimentari - Dipartimento Interventi Infrastrutturali, Area Studi e Programmazione, project 'Analisi dei sistemi seminaturali e degli agroecosistemi nei sistemi insulari mediterranei: Isola di Lampedusa e pantani di Vendicari'; and by the Marie Curie Outgoing project 'CITROVOC'. We thank Dario Caltabellotta, Antonino Drago, Fabio Guaitoli and Gabriella Matranga of the Sicily region. We are also grateful to Giovanni De Simoni and Matteo Loreto for technical help with field measurements, and to Dino Magnani and Gabriele Cencetti for help with laboratory measurements.

\section{References}

Allahverdiev AI, Irandoust S, Andersson M (1999) Chromatographic separation of $\alpha$-pinene isomerization products. Journal of Chromatography. A 848, 297-303. doi:10.1016/S0021-9673(99) 00505-1

Arbona V, Hossain Z, López-Climent MF, Pérez-Clemente RM, GómezCadenas A (2008) Antioxidant enzymatic activity is linked to waterlogging stress tolerance in citrus. Physiologia Plantarum 132, 452-466. doi:10.1111/j.1399-3054.2007.01029.x 
Arbona V, López-Climent MF, Pérez-Clemente RM, Gómez-Cadenas A (2009) Maintenance of a high photosynthetic performance is linked to flooding tolerance in citrus. Environmental and Experimental Botany 66, 135-142. doi:10.1016/j.envexpbot.2008.12.011

Baker NR, Harbinson J, Kramer DM (2007) Determining the limitations and regulation of photosynthetic energy transduction in leaves. Plant, Cell \& Environment 30, 1107-1125. doi:10.1111/j.1365-3040.2007. 01680.x

Bilger W, Björkman O (1991) Temperature dependence of violaxanthin deepoxidation and non-photochemical fluorescence quenching in intact leaves of Gossypium hirsutum L. and Malva parviflora L. Planta 184, 226-234. doi:10.1007/BF01102422

Calvert DV (1982) Effect of ground water quality on crops in Florida. In 'Proceedings of the Specialty Conference on Environmentally Sound Water and Soil Management. American Society of Chemical Engineering, Orlando, FL, 20-23 July 1982 '. pp. 440-444. (American Society of Civil Engineers (ASCE): New York)

Centritto M, Loreto F, Chartzoulakis K (2003) The use of low [CO2] to estimate diffusional and non-diffusional limitations of photosynthetic capacity of salt-stressed olive saplings. Plant, Cell \& Environment 26, 585-594. doi:10.1046/j.1365-3040.2003.00993.x

Choi WI, Lee SG, Park HM, Ahn YJ (2004) Toxicity of plant essential oils to Tetranychus urticae (Acari: Tetranychidae) and Phytoseiulus persimilis (Acari: Phytoseiidae). Journal of Economic Entomology 97, 553-558. doi:10.1603/0022-0493-97.2.553

Cojocariu C, Esher P, Heinz-Haberle K, Matyssek R, Rennemberg H, Kreuzwieser J (2005) The effect of ozone on the emission of carbonyls from leaves of adult Fagus sylvatica. Plant, Cell \& Environment 28, 603-611. doi:10.1111/j.1365-3040.2005.01305.x

de Gouw JA, Howard CJ, Custer TG, Fall R (1999) Emissions of volatile organic compounds from cut grass and clover are enhanced during the drying process. Geophysical Research Letters 26, 811-814. doi:10.1029/ 1999GL900076

Di Vaio C, Graziani G, Gaspari A, Scaglione G, Nocerino S, Ritieni A (2010) Essential oils content and antioxidant properties of peel ethanol extract in 18 lemon cultivars. Scientia Horticulturae 126, 50-55. doi:10.1016/ j.scienta.2010.06.010

Dicke M, Baldwin IT (2010) The evolutionary context for herbivore-induced plant volatiles: beyond the "cry for help". Trends in Plant Science 15, 167-175. doi:10.1016/j.tplants.2009.12.002

Fares S, Mereu S, Scarascia Mugnozza G, Vitale M, Manes F, Frattoni M, Ciccioli P, Gerosa G, Loreto F (2009) The ACCENT-VOCBAS field campaign on biosphere-atmosphere interactions in a Mediterranean ecosystem of Castelporziano (Rome): site characteristics, climatic and meteorological conditions, and eco-physiology of vegetation. Biogeosciences 6, 1043-1058. doi:10.5194/bg-6-1043-2009

Fares S, Gentner DR, Park J-H, Ormeno E, Karlik J, Goldstein AH (2011) Biogenic emission from Citrus species in California. Atmospheric Environment 45, 4557-4568. doi:10.1016/j.atmosenv.2011.05.066

Farquhar GD, Sharkey TD (1982) Stomatal conductance and photosynthesis. Annual Review of Plant Physiology 33, 317-345. doi:10.1146/annurev. pp.33.060182.001533

Farquhar GD, von Caemmerer S, Berry JA (1980) A biochemical model of photosynthetic $\mathrm{CO}_{2}$ assimilation in leaves of $\mathrm{C}_{3}$ species. Planta 149 , 78-90. doi:10.1007/BF00386231

Fisher K, Phillips CA (2008) The use of essential oils as anti-microbials: is citrus the answer? Trends in Food Science \& Technology 19, 156-164. doi:10.1016/j.tifs.2007.11.006

García-Sánchez F, Syvertsen JP, Gimeno V, Botía P, Pérez-Pérez JG (2007) Responses to flooding and drought stress by two citrus rootstock seedlings with different water-use efficiency. Physiologia Plantarum 130, 532-542. doi:10.1111/j.1399-3054.2007.00925.x
Genty B, Briantains JM, Baker NR (1989) The relationship between the quantum yield of photosynthetic electron transport and quenching of chlorophyll fluorescence. Biochimica et Biophysica Acta 990, 87-92. doi:10.1016/S0304-4165(89)80016-9

Gershenzon J, Dudareva N (2007) The function of terpene natural products in the natural world. Nature Chemical Biology 3, 408-414. doi:10.1038/ nchembio. 2007.5

Harborne JB (2001) Secondary metabolites: attracting pollinators. In 'Encyclopedia of life science'. (John Wiley \& Sons Ltd: Chichester)

Hatier J-H, Gould KS (2009) Anthocyanin functions in vegetative organs. In 'Anthocyanins. Biosynthesis, functions, and aApplications'. (Eds KS Gould, KM Davies, C Winefield) pp. 1-20. (Springer Science+ Business Media: New York)

Hodges DM, Nozzolillo C (1996) Anthocyanin and anthocyanoplast content of cruciferous seedlings subjected to mineral nutrient deficiencies. Journal of Plant Physiology 147, 749-754. doi:10.1016/S0176-1617 (11)81488-4

Hossain Z, López-Climent MF, Arbona V, Pérez-Clemente RM, GómezCadenas A (2009) Modulation of the antioxidant system in citrus under waterlogging and subsequent drainage. Journal of Plant Physiology 166, 1391-1404. doi:10.1016/j.jplph.2009.02.012

Hughes NM, Smith WK (2007) Seasonal photosynthesis and anthocyanin production in ten broadleaf evergreen species. Functional Plant Biology 34, 1072-1079. doi:10.1071/FP07205

Ientile R, La Mantia T, Massa B, Ruhl J (2011) I cambiamenti nell'ecosistema della Riserva Naturale di Vendicari e gli effetti sull' avifauna. (Ed Danaus)

Kennedy RA, Rumpho ME, Fox TC (1992) Anaerobic metabolism in plants. Plant Physiology 100, 1-6. doi:10.1104/pp.100.1.1

Kozlowski TT (1997) 'Responses of woody plants to flooding and salinity.' Tree Physiology Monograph No. 1 (Heron Publishing: Victoria, Canada)

Lambers H (2003) Dryland salinity: a key environmental issue in southern Australia. Plant and Soil 257, v-vii. doi:10.1023/B:PLSO.000000 3909.80658.d8

Langenheim JH (1994) Higher plant terpenoids: a phytocentric overview of their ecological roles. Journal of Chemical Ecology 20, 1223-1280. doi:10.1007/BF02059809

Levy Y, Syvertsen JP (2004) Irrigation water quality and salinity effects in citrus trees. Horticultural Reviews 30, 37-82.

Li H, Syvertsen JP, Mccoy CW, Stuart RJ, Schumann AW (2006) Water stress and root injury from simulated flooding and Diaprepes abbreviatus root weevil larval feeding in citrus. Soil Science 171, 138-151. doi:10.1097/01.ss.0000187367.31094.e5

Lichtenthaler HK, Wellburn AR (1983) Determinations of total carotenoids and chlorophylls $a$ and $b$ of leaf extracts in different solvents. Biochemical Society Transactions 11, 591-592.

Loreti E, Poggi A, Novi G, Alpi A, Perata P (2005) A genome-wide analysis of the effects of sucrose on gene expression in Arabidopsis seedlings under anoxia. Plant Physiology 137, 1130-1138. doi:10.1104/pp.104. 057299

Loreto F, Schnitzler J-P (2010) Abiotic stresses and induced BVOCs. Trends in Plant Science 15, 154-166. doi:10.1016/j.tplants.2009.12.006

Lota M-L, de Rocca Serra D, Tomi F, Jacquemond C, Casanova J (2002) Volatile components of peel and leaf oils of lemon and lime species. Journal of Agricultural and Food Chemistry 50, 796-805. doi:10.1021/ jf0109241

Maas EV (1993) Salinity and citriculture. Tree Physiology 12, 195-216.

Maxwell K, Johnson GN (2000) Chlorophyll fluorescence-a practical guide. Journal of Experimental Botany 51, 659-668. doi:10.1093/jexbot/51. 345.659

Moufida S, Marzouk B (2003) Biochemical characterization of blood orange, sweet orange, lemon, bergamot and bitter orange. Phytochemistry 62, 1283-1289. doi:10.1016/S0031-9422(02)00631-3 
Müller P, Li X-P, Niyogi KK (2001) Non-photochemical quenching. A response to excess light energy. Plant Physiology 125, 1558-1566. doi:10.1104/pp.125.4.1558

Munns R (2002) Comparative physiology of salt and water stress. Plant, Cell \& Environment 25, 239-250. doi:10.1046/j.0016-8025.2001. 00808.x

Nieves M, Martinez V, Cerdá A, Guillen MG (1990) Yield and mineral composition of "Verna" lemon trees as affected by salinity and rootstock combination. Journal of Horticultural Science 65, 359-366.

Nieves M, Ruiz D, Cerdá A (1992) Influence of rootstock-scion combination in lemon trees salt tolerance. In 'Proceedings of the International Society Citriculture Acireale, Italy'. pp. 387-390.

Paranychianakis NV, Chartzoulakis KS (2005) Irrigation of Mediterranean crops with saline water: from physiology to management practices. Agriculture Ecosystems \& Environment 106, 171-187. doi:10.1016/ j.agee.2004.10.006

Pirrotta C, Barbano MS (2011) Analysis of deformation structures in Pliocene and Quaternary deposits of the Hyblean Plateaux (south-eastern Sicily). Tectonophysics 499, 41-53. doi:10.1016/j.tecto.2010.12.003

Pitman MG, Lauchli A (2002) Global impact of salinity and agricultural ecosystems. In 'Salinity: environment - plants - molecules'. (Eds A Läuchli, U Lüttge). pp. 3-20. (Kluwer Academic Publishers: Dordrecht)

Prior LD, Grieve AM, Bevington KB, Slavich PG (2007) Long-term effects of saline irrigation water on "Valencia" orange trees: relationship between growth and yield, and salt levels in soil and leaves. Australian Journal of Agricultural Research 58, 349-358. doi:10.1071/AR06199

Ramsar (1971) In 'Convention on Wetlands of International Importance Especially as Waterfowl Habitat, Ramsar (Iran), 2 February 1971'. UN Treaty Series No. 14583.

Reighard GL, Parker ML, Krewer GW, Beckman TG, Wood BW, Smith JE, Whiddon J (2001) Impact of hurricanes on peach and pecan orchards in the southeastern United States. HortScience 36, 250-252.

Salvatore A, Borkosky S, Willink E, Bardo' N (2004) Toxic effects of lemon peel constituents on Ceratitis capitata. Journal of Chemical Ecology 30, 323-333. doi:10.1023/B:JOEC.0000017980.66124.d1

Schaffer B, Andersen PC, Ploetz RC (1992) Responses of fruit trees to flooding. Horticultural Reviews 13, 257-313.

Serra S (2011) Opportunities for biocatalysis in the flavor, fragrance, and cosmetic industry. In 'Biocatalysis for green chemistry and chemical process development'. (Eds J Tao, R Kazlauskas). pp. 221-254. (John Wiley \& Sons: Hoboken, NJ)
Sharkey TD (1996) Emission of low molecular mass hydrocarbons. Trends in Plant Science 1, 78-82. doi:10.1016/S1360-1385(96)80038-0

Sharkey TD, Bernacchi CJ, Farquhar GD, Singsaas EL (2007) Fitting photosynthetic carbon dioxide response curves for $\mathrm{C}_{3}$ leaves. Plant, Cell \& Environment 30, 1035-1040. doi:10.1111/j.1365-3040.2007. 01710.x

Storey R, Walker RR (1999) Citrus and salinity. Scientia Horticulturae 78, 39-81. doi:10.1016/S0304-4238(98)00190-3

Syversten JP, Yelenosky G (1988) Salinity can enhance freeze tolerance of citrus rootstock seedlings by modifying growth, water relations, and mineral nutrition. Journal of the American Society for Horticultural Science 113, 889-893.

Syvertsen JP, Lloyd J, Kriedemann PE (1988) Salinity and drought stress effects on foliar ion concentration, water relations, and photosynthetic characteristics of orchard citrus. Australian Journal of Agricultural Research 39, 619-627. doi:10.1071/AR9880619

Vartapetian BB (1991) Flood-sensitive plants under primary and secondary anoxia: ultrastructural metabolic responses. In 'Plant life under oxygen deprivation'. (Eds MB Jackson, DD Davies, H Lambers). pp. 201-216. (SPB Academic Publishing: The Hague)

Wohlfahrt G, Bahn M, Haubner E, Horak I, Michaeler W, Rottmar K, Tappeiner U, Cernusca A (1999) Inter-specific variation of the biochemical limitation to photosynthesis and related leaf traits of 30 species from mountain grassland ecosystems under different land use. Plant, Cell \& Environment 22, 1281-1296. doi:10.1046/j.1365-3040. 1999.00479.x

Wullschleger SD (1993) Biochemical limitations to carbon assimilation in $\mathrm{C} 3$ plants - a retrospective analysis of the $\mathrm{A} / \mathrm{C}_{\mathrm{i}}$ curves from 109 species. Journal of Experimental Botany 44, 907-920. doi:10.1093/jxb/ 44.5.907

Yamasaki Y, Kunoh H, Yamamoto H, Akimitsu K (2007) Biological roles of monoterpene volatiles derived from rough lemon (Citrus jambhiri Lush) in citrus defense. Journal of General Plant Pathology 73, 168-179. doi:10.1007/s10327-007-0013-0 